\title{
Barriers to Household Investment in Residential Energy Conservation: Preliminary Assessment
}

December 1982

Prepared for the U.S. Department of Energy under Contract DE-AC06-76RLO 1830

Pacific Northwest Laboratory Operated for the U.S. Department of Energy by Battelle Memorial Institute 


\title{
DISCLAIMER
}

This report was prepared as an account of work sponsored by an agency of the United States Government. Neither the United States Government nor any agency thereof, nor any of their employees, makes any warranty, express or implied, or assumes any legal liability or responsibility for the accuracy, completeness, or usefulness of any information, apparatus, product, or process disclosed, or represents that its use would not infringe privately owned rights. Reference herein to any specific commercial product, process, or service by trade name, trademark, manufacturer, or otherwise, does not necessarily constitute or imply its endorsement, recommendation, or favoring by the United States Government or any agency thereof. The views and opinions of authors expressed herein do not necessarily state or reflect those of the United States Government or any agency thereof.

\author{
PACIFIC NORTHWEST L.ABORATORY \\ operated by \\ BATTELLE \\ for the \\ UNITED STATES DEPARTMENT OF ENERGY \\ under Contract DE-AC06-76RLO 1830
}

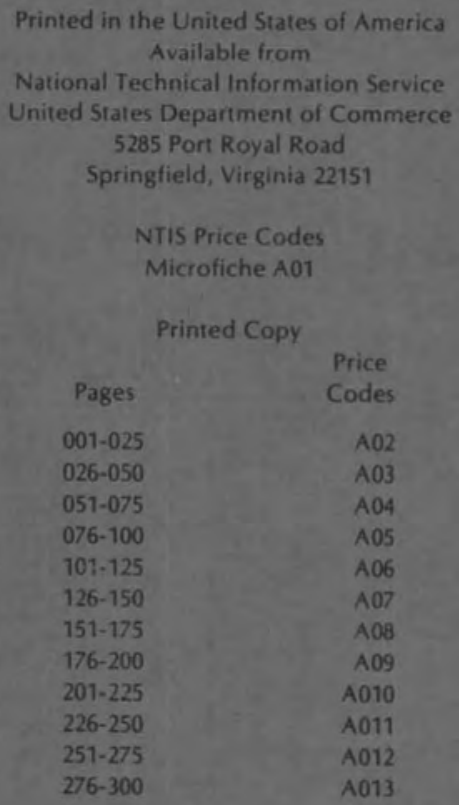


BARRIERS TO HOUSEHOLD INVESTMENT IN RES IDENT IAL ENERGY CONSERVATION:

PRELIMINARY ASSESSMENT

W. L. Hoffman, Principal Investigator (a)

A. L. Nieves, Project Manager

December 1982

Prepared for

the U.S. Department of Energy

under Contract DE-ACO6-76RLO 1830

Pacific Northwest Laboratory

Richland, Washington 99352

(a) Now with the National Institute for Social and Economic Research, Boulder, Colorado 


\section{Acknow legements}

Preparation of this report was accomplished while the Principal Investigator, W. L. Hoffman was a researcher with the Urban Institute, Washington, D.C. Financial support for data collection on which the present analysis was based was provided under a grant $(\$ 8150284)$ to the Urban Institute from the Ford Foundation. 
TABLE OF CONTENTS

$\underline{\text { Page }}$

Introduction and summary $\ldots \ldots \ldots \ldots \ldots \ldots \ldots \ldots \ldots \ldots \ldots \ldots \ldots \ldots \ldots \ldots$

I. Identifying the Major Barriers to Improvements

in Home Energy Efficiency ........................ 9

II. Interest in Energy Audits - Barriers

to Better Information ............................ 29

III. The Payback to Conservation Investment:

Household Experiences and Expectations ............... 38

IV. The Potential for Increased Energy Efficiency:

A Comparison of Household Perceptions and Audit

Recommendations .............................47

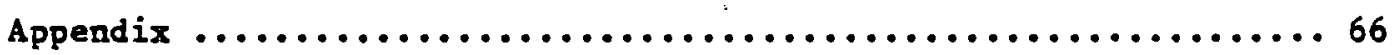


Table I-I

Reasons for not Ondertaking Additional

Page No.

Investment to Improve Home Energy Efficiency.....12

Table I-2 Frequencies of Various Types of Conservation

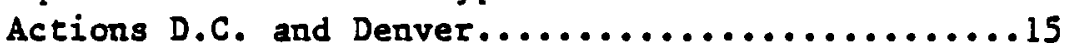

Table I-3 Relationship Among Various Measures of Conservation Activity.....................17

Table I-4 Distribution of Major Reasons Cited for Not Making Additional Conservation Improvements..........20

Table I-5 Relationship Between Various Conservation Action and Demographic Factors...................23

Table I-6 Multiple Regression Results for Predicting Current Conservation Status and Conservation Efforts.....................26

Table II-1 Characteristics of Households Requesting a Free Energy Audit...........................

Table II-2 Multiple Regression for Predicting Request for

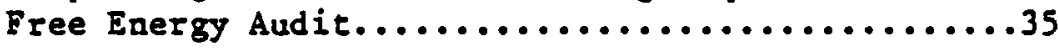

Table III-1 Households' Past and Expected Savings from Energy Conservation.....................40

Table III-2 Distribution of Payback Periods for Past and Future Efficiency Investments..............43

Table III-3 Relationships Among Investment Costs and Length of Payback.......................

Table IV-1 Comparison of Characteristics of Audited and Unaudited Households: D.C. and Denver..........51

Table IV-2 Weatherization Improvements Identified by the Energy Audit and by Households Receiving Audits............................ 44

Table IV-3 Accuracy of Household Perceptions of Needed Conservation Improvements.................58

Table IV-4 Characteristics of Households with Knowledge of Needed Weatherization Improvements...........62

Table A-1 Comparison of Evaluation of Major Features Among Three Utilities Providing Audits..........68 
INTRODUCTION AND SUMMARY

Overview

This report presents results of phase one analysis of a two phase effort to identify ways of overcoming barriers to homeowner investment in improved home energy efficiency. Phase one analysis has focused on four separately treated but related topics:

- The frequency and distribution of self-identified obstacles to additional conservation investment and the characteristics of households who have been active in making energy conserving improvements to their homes.

- The characteristics of households who seek conservation information by requesting a home energy audit.

- The degree to which the length of payback (costs of installng conservation items divided by savings in energy bills) relates to household decisions to make conservation investments.

- The extent of household knowledge about the economically attractive options for reducing energy costs which remain for their homes.

The second phase of this work will focus on the effectiveness of home energy audits as provided by utility companies under the federally mandated Residential Conservation Service (RCS) program. The subsequent analgsis and report will assess the degree to which audits stimulate additional conservation effort and improve household knowledge of the improvements which would offer substantial energy bill savings.

These two reports will be final products of a project initiated in 1981 by the Urban Institute to identify "the residential conservation gap" - the economically attractive but underutilized options for retrofit of homes to reduce energy consumption and lower overall energy 
costs.1 To pursue this study within a very limited budget, we selected a case study approach with original data collection. The analysis in this report is based entirely on two original data sources:

- a baseline survey conducted in the homes of respondents in selected low-to-moderate income neighbor hoods in Washington, D.C. and Denver, Colorado;

- an on-site energy audit conducted in a subsample of households to determine the costs and annual energy savings that could result from improvements in the dwelling unit.

A third phase of data collection has also been completed and this new information will be the basis of the analysis of energy audit effectiveness in the final report. Third phase data collection included:

- a follow-up telephone survey to baseline sample households in both cities;

- a telephone interview with two control samples of 100 households in each site who had not been previously contacted.

The baseline survey questionnaires were administered during early sumer and early fall 1981 respectively in D.C. and Denver. A total of 631 interviews in the homes of sample respondents were completed. (D.C. $N=277$; Denver $N=354)$. The survey was used to collect basic socioeconomic information on the household and characteristics of the dwelling unit, as well as information on household energy use habits, past and planned conservation activities, and on perceived barriers to further conservation improvements. The energy audits, representing

1. Initial data collection for the larger study was supported by a special grant from the Ford Foundation. Analyses of the data and preparation of a special report on the conservation efforts of elderly households was supported by contract funds from the Environmental Protection Agency and the Council on Environmental Quality. This previous report is: The Elderly and the Conservation Gap; project report \#3030-01; (December, 1981) by Wayne Hof fman. 
detailed on-site inspections, were conducted for about 25 percent of the sample households by participating utility companies using their Home Energy Audit procedures developed under Federal Residential Conservation Service (RCS) regulations. The audit results are the basis for an evaluation of alternative weatherization improvements in terms of costs and energy savings based on existing consumption patterns. A summary report based on the audit was presented free to each participating household and was provided to The Urban Institute for use in this study. ${ }^{2}$

The follow-up and control sample surveys were conducted by phone to limit data collection costs. These surveys involved shorter questionnaires which were appropriate for use in a phone interview format. The questionnaire for "previously contacted" households focused exclusively on the type and timing of recent conservation actions with a special supplemental section for households who said they had received an audit since our first interview. 3 The supplemental form asked for specific recall of recommendations presented by audit and for the respondent's evaluation of the audit's usefulness. The "new" control sample questionnaire covered not only conservation activity but also selected information on household demographics, on dwelling unit characteristics and on other factors comparable to that in the baseline questionnaire.

2. Audits were paid for by The Urban Institute and/or provided free by the utilities participating in this study. Audited households agreed to the use of audit data for study purposes.

3. The majority of audited households were those who were audited as part of the study but the supplemental questions were also asked of households who had received an audit by other means. 
A description and rationale for the original study design appears elsewhere. 4 It is useful here to mention some of the main strengths and limitations of the design for the purposes of this and the planned subsequent analysis. The main limitation is that the samples of households are not nationally representative. Thus, the frequency of demographic and conservation attributes can not be extropolated to larger universes. Measures of conservation activity in particular probably vary by climate, type of unit, development of housing patterns, and in the costs of energy and conservation measures. We structured the analysis primarily to focus on relationships among attributes, a procedure that provides great analytic advantage when universes are not represented.

The two samples, each representing a case in this study, were drawn from neighborhood sites in two cities. The city sites were selected because they were roughly similar (but not identical) in climate (heating and cooling degree days) and in the availability of active utility home audit programs. The sites are dissimilar in building practices, energy prices and public and govermental interest in residential energy conservation. In addition, the specific neighborhoods were chosen to include low-to-moderate income households, relative stability (low-turnover and moving rates), primarily older housing stock (constructed pre-1965), with diversity in structure type and a low density

4. See The Residential Conservation Gap Study: Purpose, Research Design and Data Description, U.I. Project Report \#3030-01, October 1981 by Wayne Hoffman for the rationale for the study design; sample selection and tabulation of raw responses to the baseline survey. 
of large multi-unit apartment building.5 These criteria intentionally produced an over-sampling of dwelling units likely to require, and to exhibit variety in, the potential for energy savings. They also produced an undersampling of renters who are not a prime interest in this analysis.6 The two cases permit testing for consistency in relationships of interest in the study. Analysis is performed and shown separately for each site throughout this report.7

Summary of Findings and Organization of this Report

This summary reports finding on patterns of relationships (or lack thereof) which are tentative but are evident in data from both study

5. The original data collection was also designed to over-sample units occupied by elderly persons who were the focus of previous research using these data bases.

6. The renters in the sample are most often excluded in our analysis. The radically different incentives for conservation that apply to renters make consideration of them more appropriate in a separate study. Renters who are in our sample tend to be more similar to homeowners than are all renters. Sample renters live in small, mostly single family structures, and have longer average tenure.

7. An additional limit on study findings was an unintended result in the research plan. We had hoped to perform energy audits in one-half of sampled households at both sites. All households interviewed were invited to have a free energy inspection requiring only a two hour time coumitment and authorization to the Institute to use results in statistical analysis. Households would receive free the results of the audit in a report usually costing $\$ 15$ when performed by utilities for their customers. About 60 percent of households signed the request. However, for various reasons only about 30 percent completed audits and only 25 percent are in a form used in the analysis in this report.

Reasons for the drop off are not explored in this report. However, the major source of incompleted audits are households who changed their minds, could find no time for the audit, or could not be contacted in several telephone attempts. An additional source of drop off was error in utility company recordkeeping. About 15 percent of the audits that were completed for our samples could not be drawn from the companies' master computer files by use of unique identification codes as was originally planned. This problem varied substantially among the utilities involved. While providing interesting information on the difficulty of offering free audits, this result has required a special analysis (section IV) of possible bias in the characteristics of households audited. 
sites. Section I reports analysis of barriers to energy conservation using a combination of two analytic approaches. We first examine the frequency of and distribution of self-identified barriers to further conservation investment.

- The three resons most frequently identified by homeowners are the inability to afford additional improvements, uncertainty about what needs to be done or whether it would save enough money/energy and the belief that nothing further can be done because the home is well insulated. This finding is consistent with common speculation about the major barriers and with the few other empirical studies that have addressed this issue.

- Other hypothesized barriers including: difficulty in dealing with conservation markets (finding reliable contractors), concern over disruption of the home - (renovation/redecorating) resulting from major improvements, and concern that energy improvements would not add to the value of the home are identified by some owners but are very infrequent as reasons for not making additional improvements.

- As expected, the dominant reason for not making efficiency improvements among renters is the fact they do not own the structure.

A second approach to identifying obstacles relies on the observed variation in the characteristics of households who have been as active (versus inactive) in making conservation efficiency improvements. As alternative proxies for financial and informational barriers, total household incowe and years of formal education were related to various measures of activity.

- Income and education are not highly related to conservation activity, particularly when the number of major efficiency improvements over the entire period of tenure is used as the measure of activity. In multi-variate regression analysis which reflects the correlation of these factors with length of tenure and "life cycle" of the household, income and education tend to be insignificant. 
0

Conservation status of the home when moving in, the

length of tenure, and household member period in ife-cycle may be more important factors leading to improvements in residential thermal efficiency. This suggests an alternative bases for understanding barriers to conservation investment: the apparent correlation of conservation effort with socioeconomic status masks the effects of tenure duration, iffe-cycle, and past efforts to weatherize the home on efforts to make additional needed improvements.

Section II of this report examines the relationship of similar factors to households' interest in receiving a free energy audit (measured by willingness to sign a form requesting an audit):

- Households' willingness to accept the energy audit was not highly related to socio-economic status although (significant but small) correlations with education were observed. Long term residents and older households were significantly less interested in the audit.

- Current thermal status of the unit was not significantly related to audit interest; households active in conservation were (slightly) more interested in the audit.

- The predisposition toward conservation action (activities already planned-and belief that energy savings potential in the unit was high) were significantly related to audit interest.

Section III of this paper assesses rates of return that underly household investments in major conservation improvements. The rates of return are approximated by calculating an implicit monthly payback based on past or planned expenditures for major improvements and respondents report of experienced or expected monthly savings from these improvements.

- The majority of households who have installed or who plan improvements say that the investment has only helped to keep their total home energy costs constant as energy prices rose. 
- Average implied payback periods for those reporting net positive savings from investment are in the range from 26 to 60 (winter) months which, on an approximated annual bases, yields four to ten year paybacks, or an (undiscounted) rate of return of 10 to 25 percent.

- Average length of past or future payback is not systematically related to demographic or economic characteristics of households.

- Experience with (high) rates of return on past investments is not related to expected (high) rates of return on planned investments.

Section IV of this report provides a special analysis of household knowledge of economically attractive investments by comparing high payback improvements specified by the energy audit with the list of "needed" or "desirable" conservation improvements identified by respondents.

- No more than 30 percent of households could identify one or more items which the audit identified as offering a "high" payback (contractor installed cost with payback in 5 years or less). Correct identification tended to be greater however, for higher cost items-like insulation-than for the lower cost improvements like caulking, water heater insulation or clock thermostats.

- Years of formal education is positively (but weakly related) to proportion of identifications which match audit recommendations; households more active in installing major improvements in the past were markedly less likely to identify high payback conservation improvements remaining for their units.

- Typically, households were equally (or more likely) to identify improvements which had low payback (more than ten years) as they were to identify rapid payback improvements.

The Appendix included with this report provides a comparison of selected energy savings estimates from the audits of the three utility companies which participated in the study. It also includes sample copies of the audit results forms provided to the participating households. 


\section{IDENTIFYING THE MAJOR BARRIERS TO IMPROVEMENTS \\ IN BOME ENERGY EFFICIENCY}

\section{Introduction}

The purpose of this section is to provide a general assessment of the range of barriers which impede household investments in weatherization and other energy efficiency improvements for their homes. The premise of this analysis, and, indeed that of the entire project, is that substantial economically attractive opportunities for investment remain in the nation's residential dwellings.1 The ultimate goal of this and related research is to provide a greater understanding of why the potential is under utilized or, put in other words, why the pace of investment is slower than what a simple economic model of investment might suggest.

Much speculative and empirical literature which is available on this subject suggests a consensus on two major obstacles to investment. 2 These investment impediments are:

- Financial barriers - the high initial cost of major weatherization improvements (improved insulation, storm windows, etc.) impedes homeowner purchase of these items even if the energy savings in the short

1. This is the consensus of many studies which include: Saving Energy In America's Homes: The Problems and Prospects of Federal Regulation ed. by $\mathrm{L}$. Yap, (Urban Institute Press), in press; and Energy Future: Report of the Energy Project at Harvard Business School ed. by Robert Stobough and Daniel Yergin. (Random House, New York, 1979); and "Drilling For Oil and Gas in Our Houses" by Robert $\mathrm{B}$. Williams and Marc H. Ross, in Technology Review, March/April, 1980 pp. 24-36., and The Least Cost Energy Strategy by Steve Carhart, et al., Mellon Institute for Energy Productivity, 1980.

2. In Residential Energy Conservation Volume 1, (G.P.0. 非52-00300691-0, Washington, D.C.), The Office of Technology Assessment lists these and other factors which lead to imperfections in the "energy services market." 
run would be substantial. The perceived unavailability of loans for conservation investment and the general reticence of househlds to finance home improvement on borrowed funds are components of the financial barrier;

- Rnowledge barrier - Households' lack general knowledge about remaining oportunities for savings (believe nothing more is to be done) and lack specific knowledge about conservation material and practices which may (often at low-cost) provide attractive energy savings.

In the initial proposal leading to this contract, we hypothesized related and additional factors which wight act as barriers to conservation investment. These included:

- The uncertainty and difficulty attached to calculating the rates of return for major conservation inves tments;

- Inexperience in dealing with the markets that supply conservation products (difficulty in finding reliable contractors);

- Belief that conservation investments do not add to the value of the home (cannot be recouped if the home is sold.

Detailed examination of the issues surrounding technical knowledge about conservation items and the calculation of payback to energy investments is provided in the subsequent section of this paper and in the final report.

This section provides an overview of the relative importance of these obstacles to conservation using two approaches. First, we present information on self-identified barriers to conservation collected from households during our baseline interview. Secondly, we examine the characteristics of active and inactive households classified by various measures of conservation activity. One focus of both analysis is on the 
effects of household income and formal education (as rough indicators of financial and knowledge constraints) on a conservation activity.

\section{Self-Identified Barriers}

As part of our initial in-home survey, we asked respondents to specify the most important reasons why they would not make additional conservation improvements to their homes. 3 Because this was an openended question, a wide range of responses were possible. Permissible answers included the response that "no additional improvements were necessary." We have classified these responses carefully trying to reflect the essential barrier represented by each answers. (The first two responses of each household were examined).

Table I-1 shows the classification and distribution of the most frequently mentioned responses in each study site. By large proportions the three most frequent responses in both sites were financial barriers, lack of knowledge about what would save the most money, and the belief that nothing more needs to be done (13 to 53 percent of respondents). Other responses related to hyporhezed barriers - that reliable contractors were hard to locate or contractors were difficult to deal with, that improvement wouldn't add to the value of the home, or that the work would disrupt the home were for less frequently cited by both samples (less than 7 percent).

At the initiation of this study, we decide to focus primarily on homeowners because the incentives for renters to invest in conservation

3. This question appeared after several others which dealt with the past and planned conservation activity of the household and was in the later half of the interview. 
TABLE I-1

REASONS FOR NOT UNDERTAKING ADDITIONAL INVESTMENT TO IMPROVE HOME ENERGY EFFICIENCY ${ }^{a}$

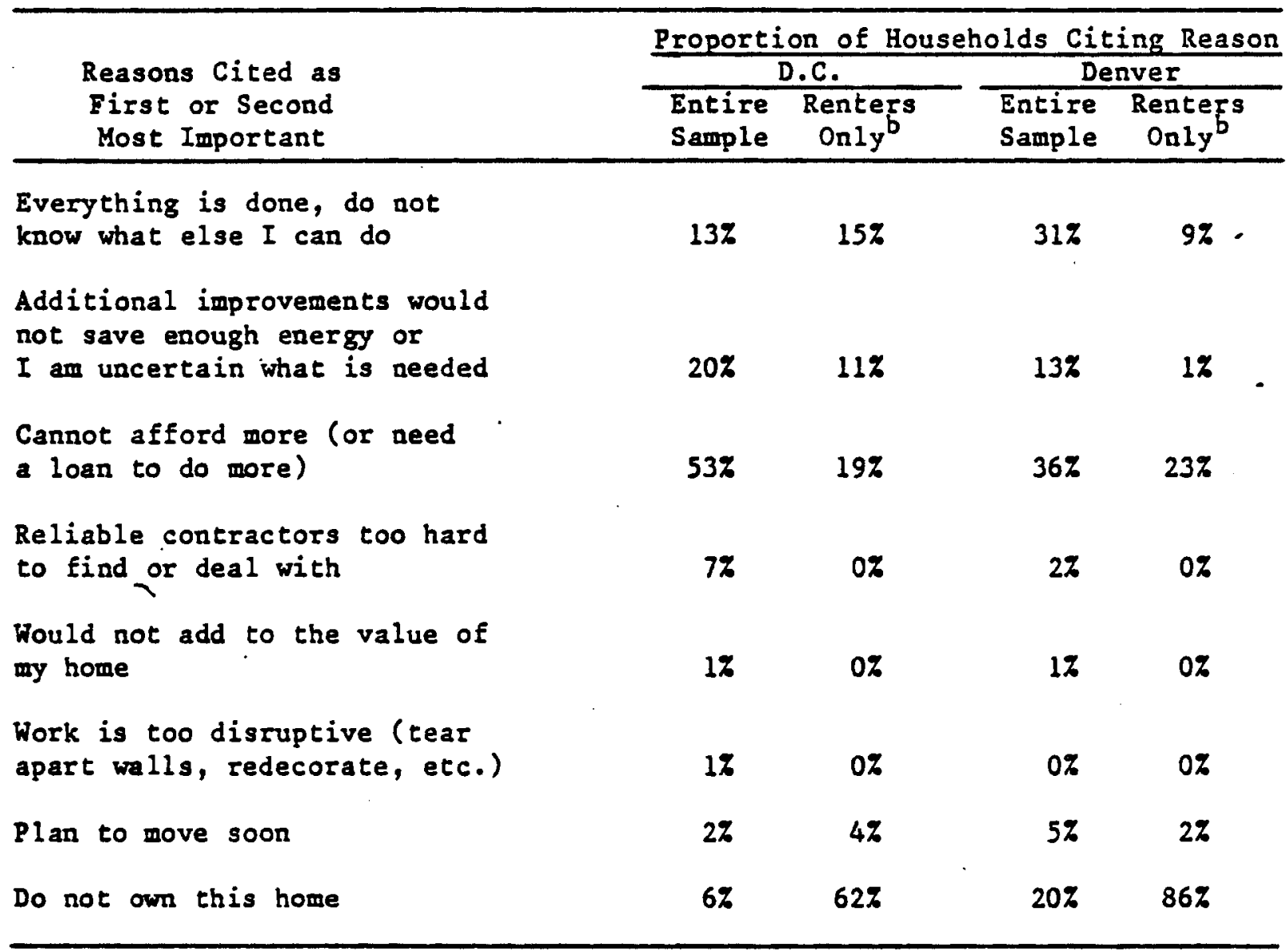

a. These are responses to open-ended questions on main reasons for not making additional energy saving improvements (first or second mention).

b. Renters were under-represented in the samples; about 9 percent in D.C. and 21 percent in Denver. 
would be substantially different and deserving of separate treatment. In the response distribution of the entire sample, we see that 6 percent (D.C.) and 20 percent (Denver) of respondents identified the main reason for inaction as "Don't Own this Home". This reason documented all other responses among renter households ( 62 and 86 percent).

The remaining reasons that we were able to classify included mention that the household planned to move soon. In Denver, this response was as common among owners as renters. ${ }^{4}$

In summary, it appears that at least at the level at which respondents can articulate reasons in response to an open-ended query, the major obstacles to further investment among howeowners are related to costs of conservation items, lack of general and specific knowledge about conservation options, and the belief that no other improvements are needed. The low frequencies with which we could find responses related to contracting and concern about the capitalized value of home conservation improvements suggest that as formulated these hypothezed barriers are not common. How the frequent barriers are distributed among types of households will be considered after identifying the types and frequency of conservation activity evident in the sample.

\section{Types of Conservation Effort}

Our baseline interview was also designed to obtain both a current and retrospective picture of household conservation actions. For each major conservation feature in place-attic and wall insulation-storm

4. About 97 of responses could not be classified into these categories. None were mentioned frequently enough to warrant a separate classification. 
windows and storm doors-we are able to determine whether the initial installations of the item or additions/improvements to the item were performed by the current resident. We also obtained information on other major (floor insulation, solar) and "non-major" efficiency improvements including items such as caulking and weatherstripping and on efforts to curtail energy use. The latter include specific mention by respondents of changes in family habits to, for instance, lower space and water heating temperatures settings, or to use air conditioning and appliances less frequently. It was not possible to weigh or to scale the difficulty of these various types of conservation activity into an overall measure of conservation effort. However, we assess the range of variation in each of these various measures and in measures which sumarize combinations of activity.

Table I-2 provides information in the distribution of conservation actions in each study site. While only 19 to 30 percent of households report a major efficiency improvement recently (since 1979, top line), the proportion reporting major items ever installed is much greater. Over 57 percent report two or more in D.C. and over 47 percent report that many installations in Denver. Efforts to make other efficiency improvements and/or to curtail use is reported by over 65 percent of each sample.

A sumary measure of conservation actions-reported at the bottom of the table-indicates that only a small proportion ( 3 to 6 percent) of households were totally inactive. Over 60 percent of households report both some type of curtailment of energy use and some efficiency improvement (either major or minor) sometime since moving into their unit. 
TABLE I-2

FREQUENCIES OP VARIOUS ITPES OP CONSERVATION ACIIONS

D.C. AND DENVER ${ }^{2}$

\begin{tabular}{|c|c|c|}
\hline $\begin{array}{l}\text { Sumary Mansure of } \\
\text { Conservacion Effort }\end{array}$ & $\begin{array}{l}\text { D.C. } \\
\text { Proporeion of } \\
\text { Households: }\end{array}$ & $\begin{array}{l}\text { Denver } \\
\text { Proportion of } \\
\text { Bouseholds }\end{array}$ \\
\hline $\begin{array}{l}\text { Heve installed or added to at lease } \\
\text { one major iem since } 1979\end{array}$ & 192 & 302 \\
\hline $\begin{array}{l}\text { Number of major icem added } \\
\text { siace woving in } \\
\text { now or ore } \\
\text { Iwo or ehree } \\
\text { Pour }\end{array}$ & $\begin{array}{l}432 \\
262 \\
312\end{array}$ & $\begin{array}{l}547 \\
302 \\
17 \%\end{array}$ \\
\hline $\begin{array}{l}\text { Proportion of in-place mejorb } \\
\text { item added by curreac reoident } \\
\text { Noae } \\
\text { Op to } 502 \\
512 \text { to } 752 \\
752 \text { to } 211\end{array}$ & $\begin{array}{l}192 \\
228 \\
132 \\
462\end{array}$ & $\begin{array}{l}272 \\
302 \\
248 \\
182\end{array}$ \\
\hline 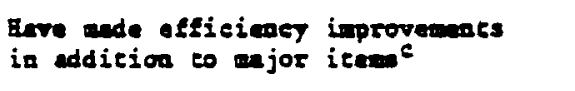 & 648 & 702 \\
\hline $\begin{array}{l}\text { Report one or wore deffores to } \\
\text { curteil }\end{array}$ & 692 & 762 \\
\hline $\begin{array}{l}\text { Aeve ande only inexpensive } \\
\text { conservation ieproverantes }\end{array}$ & 448 & 592 \\
\hline groe caulked/weatherstripped & 307 & 417 \\
\hline 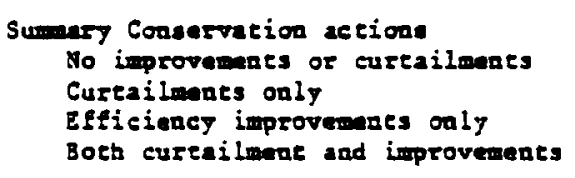 & $\begin{array}{r}37 \\
52 \\
287 \\
637\end{array}$ & $\begin{array}{r}67 \\
47 \\
182 \\
728\end{array}$ \\
\hline $\begin{array}{l}\text { Major Feacures in Placef } \\
\text { None or One } \\
\text { Two } \\
\text { Three or Four }\end{array}$ & $\begin{array}{l}10 z \\
297 \\
61 z\end{array}$ & $\begin{array}{l}117 \\
267 \\
632\end{array}$ \\
\hline
\end{tabular}

2 - Proportions are shova for hotepraers oaly.

b - Four icena are identified as anjor thermal efficieney item; actic and wall iasulation, score wiadovs and doors.

c - Additional eftieacy impovemenes any be anjor or ainor bue do not include the four an jor itew identified above. Moes coumon additional iteres are caulking and weatherstrippiag.

d - Respondent had to tantion specific offort in redueing energ use or ehanging eatergy use habits. These included: lowering spece or water heating temperztures, using appliances and lightiag less frequently, using less hot water.

- - Irexpensive ifrme have been elassified irtespective of expendicures on the item and iaclude caulking, weatherstripping, plastic wiadov coveriag, heavy curtaina, ete.

- Major features include actic and wall insulation, storm windows and doors. 
Many of these measures are by definition highly related but an indication that some type of conservation activity are relatively independent of others is provided by the correlation among items shown in Table I-3.

The number of major features in-place is highly correlated with the number of major actions undertaken by the household, implying that current status is due significantly to current resident's efforts. Measures of major conservation installations either-as number or proportion installed (items 3 and 4 )-are only moderately related to other types of actions but the strength of these relationships vary between the two sites. Particularly noteworthy are the correlations involving "efforts to curtail use" an action that is positively, but weakly, related to major conservation installations (statistically significant at .16 in Denver and insignificantly at .03 in D.C.). This is evidence that curtailment effort and major conservation improvements are unrelated actions rather than tradeoffs or alternative approaches to controlling energy costs (significant negative relationship would be evident in that case).

The use of inexpensive efficiency improvements (a subset of all the efficiency improvements other than the four major installations previously defined) is also not highly related to major actions. (The strongest correlation is .23 in Denver). Inexpensive improvements (item 5) and caulking/weatherstrippping actions (item 9) are significantly related to curtailing use (.27 and .22 in D.C. and .25 and .15 in Denver) but the positive relationship is not particularly strong. 
TABLE I-3

RRATIOASHIP AHONG VARIOUS meASURES OF COASERVATIOA ACTIVITY

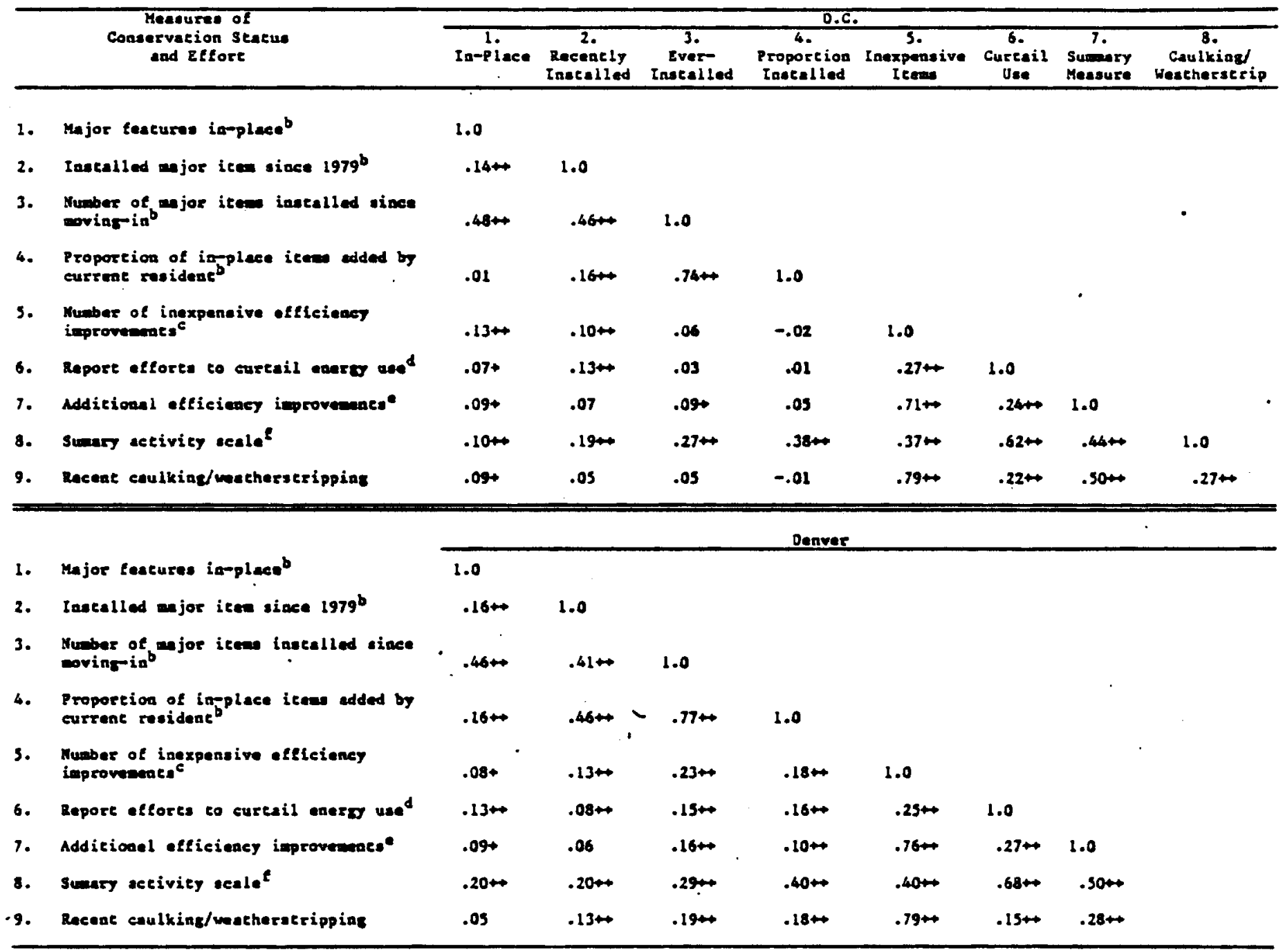

+ - indicates significance at .l level.

* - indicated siginificance at .05 level.

a - Corralacione are Pearson'. R.

b - Major feacures referted to are attic and wall inaulation, store vindowe and doors.

c - Number of inexpeneive efficiency investmence are other then the four ajor festures idencified above and inelude caulking/wacherecripping, weer heater insulacion, plactic windou coverings or heavy drapae, clock chermolacs.

$d$ - This variable is coded "q" if iny epecific effort co curcail ute or change tanily's energy uee habics are reported (o if not): includet using appliances and ligheins lese, curbing dow space and water heating towperatures, ece.

- Any additional efficiency ieprovements other than four major idencified above. Meanure is inclusive of inexpentive iteat in e above but veriable is coded " 1 " if any, "O" if wore.

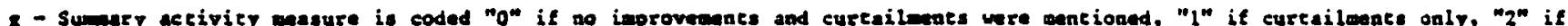
efficiency investants only, "g" if both spacific effieiency investomes and eurtailantes ware antioned. 
This evidence on the correlation among types of actions suggest that it is appropriate to consider several of these measures of conservation activity separately because they appear as discrete forms of conservation effort. Obstacles or barriers to conservation may differ with respect to these various types of activity. We follow this approach in the subsequent analysis.

\section{How the Self-Identified Barriers are Distributed}

Table I-4 presents information on the incidence of the three major reasons identified as obstacles to further investment among various demographic and conservation characteristics of households. While socio-economic status is sometimes related to the reasons mentioned by respondents in a way that meets a priori expectation, none of the - relationships are large and most are not statistically significant. Considering first the respondents' mention of financial constraints ("Can't Affort More"), the table indicates a rate of response that is lower among upper income households in both sites. This financial concern is not consistently related to formal education. Financial concerns, however, are most strikingly (and significantly) related to the period of the life cycle of the respondent's family. Middle aged adults and families with children apparently feel the greatest financial constraint although the average income of these households (data not shown) is greater than among households in the other two stages of life cycle.

We would expect the second major reason for not making additional conservation improvements-"not sure what to do"--to be less evident among better educated households. This is true in Denver (although not 
significant) and not at all evident in D.C. Based on income, the response is more frequent among the higher socio-economic groups but not statistically significant.

Households reporting that they do not believe additional conservation improvements are needed are found more frequently among the lowest income group but least frequently among middle income income groups. This patterm is neither monotonically consistent or statistically significant for education.

The most striking variation in the response pattern-reporting that additional improvements are not needed-is found with the life cycle classification with the highest response among the older households (statistically significant in Denver).

In general, it appears that the distribution of the major selfidentified barriers to additonal conservation are not well or simply understood on the bases of socio-economic status attributes while lifecycle factors offer some tentatively meaningful results. We anticipate that life cycle correlation with "Not needed" response may be related better to past activity levels rather than the life cycle difference itself.

The bottom portion of table I-4 shows the distribution of barriers among households with differing conservation activity rates. Some of these patterns bear closer scrutiny. The response that no additional improvements are needed significantly and consistently relates to two measures of major conservation actions and to the current status of the dwelling unit (classified by presence of major items). Whether or not 
TABC: I-4

DISTRIBUTIOA OF MAJOR RBASONS CITED FOR NOT MATNG ADDITTORAL COASEBVATION IMPROVRARNTS ${ }^{2}$

\begin{tabular}{|c|c|c|c|c|c|c|}
\hline $\begin{array}{l}\text { Socio-Demographic } \\
\text { and } \\
\text { Conervacios Chareceristics }\end{array}$ & $\begin{array}{c}\text { Not } \\
\text { Meoded }\end{array}$ & $\begin{array}{l}\text { D.C. } \\
\text { Whet Sure } \\
\text { To Do }\end{array}$ & $\begin{array}{c}\text { Cannor } \\
\text { Afford } \\
\text { More }\end{array}$ & $\begin{array}{c}\text { Hor } \\
\text { Sieeded }\end{array}$ & $\begin{array}{l}\text { Dequer } \\
\text { Not Sura } \\
\text { Whic } \\
\text { To Do }\end{array}$ & $\begin{array}{l}\text { Cannot } \\
\text { Afford } \\
\text { More }\end{array}$ \\
\hline $\begin{array}{l}\frac{\text { Household Incoses }}{\text { Lass chan } \$ 10,000} \\
\text { \$10,000-15,000 } \\
\text { Mote than } \$ 15,000\end{array}$ & $\begin{array}{r}177 \\
82 \\
137\end{array}$ & $\begin{array}{l}177 \\
237 \\
237\end{array}$ & $\begin{array}{l}617 \\
608 \\
538\end{array}$ & $\begin{array}{l}467^{7} \\
297 \\
348\end{array}$ & $\begin{array}{l}77^{2+1} \\
247 \\
207\end{array}$ & $\begin{array}{l}487^{*} \\
458 \\
342\end{array}$ \\
\hline $\begin{array}{l}\frac{\text { Edreacionb }}{\text { Less than hifh school }} \\
\text { Bigh shool } \\
\text { More than high school }\end{array}$ & $\begin{array}{l}17 \\
102 \\
12 \pi\end{array}$ & $\begin{array}{l}217 \\
202 \\
222\end{array}$ & $\begin{array}{l}352 \\
602 \\
532\end{array}$ & $\begin{array}{l}387 \\
397 \\
197\end{array}$ & $\begin{array}{r}202 \\
15 z \\
72\end{array}$ & $\begin{array}{l}422 \\
357 \\
447\end{array}$ \\
\hline 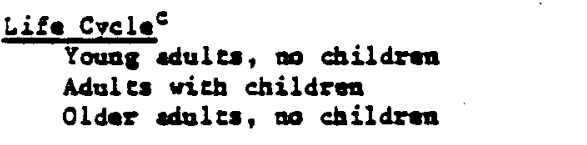 & $\begin{array}{r}02 \\
122 \\
172\end{array}$ & $\begin{array}{l}132 \\
192 \\
292\end{array}$ & $\begin{array}{l}382^{+\infty} \\
647 \\
312\end{array}$ & $\begin{array}{l}237^{m} \\
282 \\
637\end{array}$ & $\begin{array}{l}275 \\
178 \\
125\end{array}$ & $\begin{array}{l}317^{m} \\
487 \\
238\end{array}$ \\
\hline $\begin{array}{l}\frac{\text { Previoue Conservation }}{\text { None }} \\
\text { Cusbecke only } \\
\text { Som effieiency inveetmants }\end{array}$ & $\begin{array}{r}0 \pi \\
0 \pi \\
14 \pi\end{array}$ & $\begin{array}{l}132 \\
397 \\
207\end{array}$ & $\begin{array}{l}882 \\
548 \\
562\end{array}$ & $\begin{array}{l}387 \\
257 \\
387\end{array}$ & $\begin{array}{l}387^{*} \\
177 \\
157\end{array}$ & $\begin{array}{l}137^{*} \\
337 \\
412\end{array}$ \\
\hline $\begin{array}{l}\text { Number of Meior Actiongd } \\
\text { Lon } \\
\text { Yedium } \\
\text { Bigh }\end{array}$ & $\begin{array}{l}52^{50} \\
122 \\
242\end{array}$ & $\begin{array}{l}192 \\
202 \\
232\end{array}$ & $\begin{array}{l}667^{m} \\
57 \% \\
45 \%\end{array}$ & $\begin{array}{l}257^{5} \\
477 \\
572\end{array}$ & $\begin{array}{r}202 \\
167 \\
92\end{array}$ & $\begin{array}{l}46 \pi^{*} \\
312 \\
34 \pi\end{array}$ \\
\hline$\frac{\frac{\text { Resent Major Actioned }}{\text { Note }}}{\text { Sane }}$ & $\begin{array}{l}132 \\
128\end{array}$ & $\begin{array}{l}218 \\
212\end{array}$ & $\begin{array}{l}602^{*} \\
462\end{array}$ & $\begin{array}{l}382 \\
362\end{array}$ & $\begin{array}{l}192 \\
122\end{array}$ & $\begin{array}{l}387 \\
487\end{array}$ \\
\hline $\begin{array}{l}\text { Presence of Major I cees } \\
\text { Poorly wacherized } \\
\text { Moderace } \\
\text { Wall wacherized }\end{array}$ & $\begin{array}{l}4 I^{+\infty} \\
82 \\
162\end{array}$ & $\begin{array}{l}242 \\
182 \\
222\end{array}$ & $\begin{array}{l}682 \\
632 \\
522\end{array}$ & $\begin{array}{l}147^{+1} \\
177 \\
497\end{array}$ & $\begin{array}{l}172 \\
242 \\
142\end{array}$ & $\begin{array}{l}622^{* 10} \\
947 \\
292\end{array}$ \\
\hline 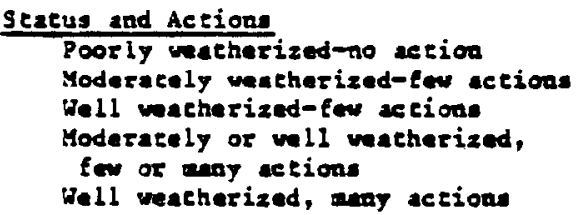 & $\begin{array}{r}92 \\
102 \\
02 \\
208 \\
148\end{array}$ & $\begin{array}{l}172 \\
302 \\
217 \\
218 \\
232\end{array}$ & $\begin{array}{l}682 \\
502 \\
637 \\
457 \\
562\end{array}$ & $\begin{array}{l}222 \\
102 \\
437 \\
352 \\
492\end{array}$ & $\begin{array}{l}222 \\
242 \\
237 \\
187 \\
102\end{array}$ & $\begin{array}{l}632 \\
527 \\
232 \\
422 \\
327\end{array}$ \\
\hline
\end{tabular}

* Significane at .1 level.

* Significane ac .05 level.

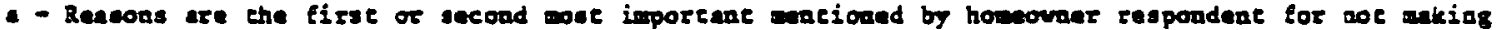
additionsl efficiency improvements.

b - Edueacion is for mose adueated of housenold.

c - Toung adules ase under ase 33, older sdules sze over age 60.

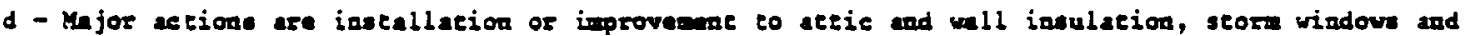
doors. Recene ectione aze since 1979. 
these perceptions are warranted, it is clear that past effort and crude measures of weatherization affect perceptions about remaining potential. Financial constraints exhibit some significant but weaker relationships with past actions. Again, the number of major efficiency improvements and the current status of the unit seem to be inversely related to the frequency of response on financial constraints. Other measures of conservation action are not consistently related.

"Not sure what to do" as a major barrier is not related to conservation activity measures, with one exception: in Denver, those who report no action of any type are significantly more likely to cite this reason than are those who report either cutbacks or efficiency investments. This finding is doubtful in light of a non-comparable distribution in D.C.

\section{A Second Approach to Assessing Conservation Barriers}

While the reasons offered by households explaining their rational for not investing in additional conservation are plausible, the pattern of response overall is not highly or consistently related to socioeconomic attributes as we had expected. Believing that further improvements are not needed (and financial constraints to a lesser degree) is related to the extent of previous activity. Uncertainty about what to do is not highly related to socio-economic variables or past activity.

A second approach which may be used is direct examination of the socio-economic attributes of households whose rates of conservation activity differ. In this case, we may correlate household socioeconomic characteristics with the various measures of conservation 
activity previously specified for each of our samples. The consensus of previous work is that higher socio-economic status households (interpreted as those with lower financial constraints, and greater general knowledge and sophistication about conservation options) engage in more conservation effort.5 One contribution of our approach over that previous work is the use several alternative measures of conservation effort including those that reflect investment over the entire period of tenure.

Table I-5 presents simple bi-variate relationships between four selected household characteristics representing socio-economic status, period in life cycle and tenure duration and various measures of conservation effort. We consider the findings for the specific measures of activity.

Income and education both show several significant relationships with conservation actions and status but these relationship are generally weak and not important in many instances. These socioeconomic variables appear related to the current status of the unit, to recent major installations to "other non-major efficiency improvements and to efforts to curtail use. They are not related to number of major efficiency improvements ever made and are slightly negatively related to

5. For regression estimation of conservation actions see Hirst, Eric et al., Residential Energy Use and Conservation Action: Analysis of Disaggregate Household Data Oak Ridge National Laboratory, (ORNL/CON - 68), March, 1981; see also, Berry Linda et al.; Review of Evaluation of Utility Home Audit Programs Oak Ridge National Laboratory, (ORNL/CON) March, 1981, which reviews findings of numerous other studies. Most studies have compared the distribution of demographic attributes in the information available from audited households with that of the larger utility service area population to conclude that socio-economic status and conservation effort are related. 
TABLE I -5

RELATIONSHIP BETWEEN VARIOUS CONSERVATION ACTION AND DEMOGRAPHIC FACTORS ${ }^{a}$

\begin{tabular}{|c|c|c|c|c|c|c|c|c|}
\hline \multirow{2}{*}{$\begin{array}{c}\text { Measures of Conservation } \\
\text { Activities and Thermal } \\
\text { Status of Merit }\end{array}$} & \multicolumn{4}{|c|}{ D.C. } & \multicolumn{4}{|c|}{ Denyer } \\
\hline & Income & Education & $\begin{array}{l}\text { Life- } \\
\text { cycle }\end{array}$ & $\begin{array}{l}\text { Length of } \\
\text { Residence }\end{array}$ & Income & Education & $\begin{array}{l}\text { Life- } \\
\text { cycle }\end{array}$ & $\begin{array}{l}\text { Length of } \\
\text { Residence }\end{array}$ \\
\hline $\begin{array}{l}\text { Number of major features } \\
\text { in-place }\end{array}$ & $.10^{\star}$ & $.10^{\star}$ & .02 & $.12^{\star \star}$ & $.17^{\star \star t}$ & .06 & .06 & $.22^{\star \star}$ \\
\hline $\begin{array}{l}\text { Number of recent major } \\
\text { efficiency improvements } c\end{array}$ & .02 & .03 & $-.13^{\star \star}$ & $-.12^{\star \star}$ & $.15^{\star \star}$ & $.09^{\star}$ & $-.10^{\star \star t}$ & $-.15^{\star \star t}$ \\
\hline $\begin{array}{l}\text { Number of major efficiency } \\
\text { improvements ever }\end{array}$ & .00 & .03 & $.12^{\star \hbar}$ & $.38^{\star \star}$ & .00 & .00 & $.15^{\star * t}$ & $.22^{\star \star}$ \\
\hline $\begin{array}{l}\text { Proportion of current in-place } \\
\text { major items installed by } \\
\text { current resident }\end{array}$ & -.06 & $-.11^{\star \star}$ & $.13^{\star \star}$ & $.37^{\star \star t}$ & -.05 & .00 & $.14^{* \star}$ & $.17^{\star \star}$ \\
\hline $\begin{array}{l}\text { Have made other recent } \\
\text { efficiency investment } 8 \text { e }\end{array}$ & $-.03^{\star}$ & .06 & -.07 & -.04 & $.08^{\star}$ & $.12^{\star \star}$ & $-.09^{\star}$ & .04 \\
\hline $\begin{array}{l}\text { Report efforts to curtail } \\
\text { energy use }\end{array}$ & $.08^{\star}$ & .07 &.- .22 & -.18 & .02 & $.09^{\star}$ & -.06 & .00 \\
\hline $\begin{array}{l}\text { Have done caulking/ } \\
\text { weatherstripping recent } 1 \text { y }\end{array}$ & .00 & .05 & $-.12^{\star \star}$ & $-.11^{\star *}$ & -.03 & -.02 & -.03 & -.05 \\
\hline
\end{tabular}

a - Correlations are Pearson's R; * significant . l two-tailed; *夫 significant at .05.

b - Counts presence of attic and wall insulation, storm windows and doors.

c - Same item as b except counts if added over period since 1979 to present.

d - Counts same items as b that were added by current resident since moving.

e - Coded as " 1 " if respondent mentions any effort to curtail use, e.g. lower thermostat setting. 
proportion of items in-place that were installed by current residents (A possible interpretation is that higher income households have moved more recently and into better weatherized homes.)

Tenure and life cycle variables appear more significant than income and education in this analysis but have both positive and negative effects on activity. Length of residence is positively related to the current status of the unit and also is strongly related to measures of effort over time-the number and proportion of major efficiency improvements ever made. Length of tenure is significantly negatively related to making recent improvements and (in D.C.) to the low-cost effort to caulk and weatherstrip. While weaker, the relationships of period in the life cycle generally mirror those of tenure duration except life cycle is unrelated to current status of the unit.

The four demographic factors are colinear in these samples and while the relationships between life cycle and tenure duration and between income and and education are positive, there is also a significant negative relationship between the two groups of factors.6 In order to sort out these effects, we have tried several regression specifications using four selected measures of conservation status or action as dependent variables in an attempt to ascertain their independent effects. Results of the most complete specification for "Current status of Unit" (major features in place), "Major Items Installed Ever,"

6. Tenure duration is correlated with income at -.22 in both samples, and at -.14 and.-10 with education. Life cycle is about.-30 with income. The correlation between income and education is between .4 and .5 and between life cycle and tenure about . 4 . 
"Recent Major Installations" and "Report Effort to Curtail Use" are shown in Table I-6.

It is immediately evident that it is difficult to predict or explain these various measures conservation status and action utilizing even key demographic attributes of households.7 The maximum $R^{2}$ in these estimates is .18 and wany of the equations are insignificant. 8

While most variables have expected signs, few are significant at even the $10 z$ level. Household income is significant only in explaining current status of unit (and only in Denver). Education is insignificant in all instances. 9

Years of residence is significant in explaining current status of the unit and in nimber of major features installed and overwhelms any life cycle effects (evident in bivariate correlations), but not significant in the recent major installations or curtailed use equations. The only significant explanation of curtailed use is the negative effect of life cycle. (The aged do not cut back on use.)

We included in the final steps of these equations, two of the three major reasons mentioned as obstacles to further investment. "Can't Afford" response appears significant with consistent negative sign in

7. Efforts to predict total conservation savings due to efficiency improvements as performed by others show more significant equations (with R2 from .14 to .41). However, the dependent variable was formulated to capture an interval measure of $B$ tu savings over a set time period, rather than conservation effort, and included as predictors an estimate of total energy use (definitionally correlated with savings). See Table 9, in Hirst et al. op. cit.

8. We included these specifications even though insignificant so that we could compare the estimated parameters of the independent variables.

9. Even in stepwise analysis, with education and income entering only after tenure duration, these variables did not achieve significance. 
TABLE 1-6

MULTIPLE REGRESSION RESULTS FOR PREDICTING CURREHT COMSERVATIOH STATUS AND CONSERVATIOH EFFORTS

\begin{tabular}{|c|c|c|c|c|c|c|c|c|c|}
\hline \multirow{2}{*}{\multicolumn{2}{|c|}{$\begin{array}{l}\text { Sumary statiatical } \\
\text { Independent Variablea }\end{array}$}} & \multicolumn{2}{|c|}{ Major Feature. In-Place } & \multirow{2}{*}{$\begin{array}{c}\text { Hajor I tema } \\
\text { D.C. }\end{array}$} & \multirow{2}{*}{$\begin{array}{l}\text { Inetalled } \\
\text { Denver }\end{array}$} & \multirow{2}{*}{\multicolumn{2}{|c|}{$\begin{array}{l}\text { Recent Major Installed } \\
\text { D.C. Denver }\end{array}$}} & \multicolumn{2}{|c|}{ Curtailed Use } \\
\hline & & D.c. & Denver & & & & & D.c. & Denver \\
\hline \multicolumn{2}{|c|}{$a^{2}$} & .04 & .11 & .18 & .08 & .08 & .05 & .07 & .11 \\
\hline \multicolumn{2}{|c|}{ F-Ratio } & 1.8 & 5.96 & 5.6. & 2.6 & 1.6 & 1.4 & 2.1 & 4.0 \\
\hline \multicolumn{2}{|c|}{ Step-at-F-Ratio Given } & A5 & A5 & 88 & B8 & 17 & B7 & 89 & B9 \\
\hline \multicolumn{2}{|c|}{ Constant } & 2.64 & 2.64 & 1.19 & .82 & .50 & .23 & .80 & .71 \\
\hline$A \mathbf{I}$ & Years at current reaidence & $.016^{\star \star *}$ & $.021^{\star \star \star}$ & $.04^{\star \star \star}$ & $.02^{\star \star}$ & -.004 & -.004 & -.005 & .000 \\
\hline $\mathbf{A 2}$ & Lifecycle $2^{\mathrm{e}}$ & -.421 & -.261 & .40 & .35 & -.096 & .025 & -.19 & -.12 \\
\hline A3 & Lifecycle $3^{e}$ & -.388 & -.078 & .18 & .30 & -.208 & .025 & $-.38^{\star}$ & -.17 \\
\hline$\$ 4$ & Household Income $(\$ 1,000)$ & .007 & $.021^{\star \star \star}$ & .004 & .005 & -.001 & .004 & -.001 & -.001 \\
\hline A5 & Education & .028 & -.002 & .003 & .000 & .010 & .002 & .009 & -.005 \\
\hline B6 & Cannot afford is wajor reasons & $8 .-.247$ & $-.494^{\star \star \star}$ & $-.37^{\star}$ & $-.37^{\star}$ & $-.14^{\star \star}$ & -.094 & -.020 & .056 \\
\hline B7 & Not oure as as jor reasons & -.121 & $-.371^{\star \star}$ & -.13 & -.13 & -.19 & .015 & -.037 & $-.32^{\star \star \star}$ \\
\hline B8 & Eatimated home value & - & - & $-.001^{\star}$ & .000 & -.22 & .000 & - & - \\
\hline B9 & Major featuree in-place & - & - & - & - & - & - & .037 & $.048^{\star}$ \\
\hline
\end{tabular}

Source: Degression reaulte and otatistical measures obtained from statistical package for ocial ecience (SPSs). Samples are homeouners only. N - about 250 and 275 respectively.

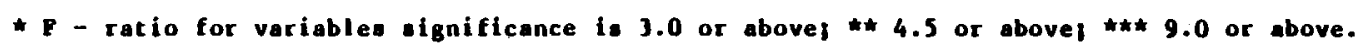

- Count of four major coneervation featurea in the units attic and wall ineulation, etorm window and doors.

b - Number of the four wajor features installed or added to by current resident.

c- Coded ' $I$ ' if any of four wajor featurea were added eince 1979 ; ' 0 ' if not.

d - Coded ' 1 ' if any opecific effort to curtail energy use is identified, ' 0 ' if not.

e - lifecycle variables are dumay variables with lifecycle 2 equal to ' $I$ ' if household has children present and lifecycle 3 equal to " 1 " if only household members are adulte over age 60 with no children present.

f - Education is in years for most educated person in houaehold.

8 - Major reason measures are responses to open-ended queation about wajor reason for not making additional conservation investments. Third major reason "not needed" is onitted becaue of high negative colinearity the with other two reasons.

h - llome value is respondent' estimate of current market value of liome. 
predicting current status (in Denver), Major Items ever Installed and Recent Major Installations (in D.C.). "Not Sure" what to do is negative in the same three equations but significant only for current status in Denver.

Summary of Findings on Barriers

This prelimiinary assessment of barriers which may impede additional conservation investment has produced very mixed results. The direct approach to identifying barriers by assessing respondents open ended responses concerning obstacles to investments seems to confirm the dominance of three general concerns (for homeowners): the belief that nothing wore is needed, that costs of possible improvements are too high or can't be financed, and uncertainty over which and whether additional improvement would provide enough savings.

It also appears that conservation effort is a multi-dimensional phenomena with various approaches-including major improvements, lowcost improvements, curtailment of use-appearing neither as cumulative nor as sharply alternative emphases in conservation by households. The major barriers identified by respondents relate only loosely to the types of actions they have taken. The most significant finding in this regard is that past-effort (major installation) is correlated with the belief that little remaining conservation needs to be done.

The second approach to identifying barriers to further investment provides little support for the hypotheses that financial cost (assumed to be measured by household income) and uncertainty over what can be done (assumed to be related to formal education) effect conservation actions. The impression suggested by our multi-variate analysis is that 
the findings of previous research on the correlations socio-economic status and conservation effort (when renters are excluded) may in fact be tenure and life cycle effects.

While not confirmed by this analysis, an alternative picture of the major obstacles to further investment might be portrayed as follows. The current energy efficiency status of the unit (as measured by major features) is a function of time. As households age and start families, they buy homes and move less frequently. During the course of tenure, various energy saving improvements are added (serially) to the home. As more immprovements are made, (irrespective to the quality of improvements, deterioration over time, or the availability of more economically attractive opportunities developing as eneryg costs rise) the household comes to believe nothing more needs to be done. These life cycle effects are of course correlated with income. If this portrait is accurately, the essential question for research may be to assess the degree to which perception about remaining conservation opportunities (or lack thereof) are accurate and to identify how the degree of inadequate knowledge about conservation potential is distributed. The subsequent question is how might these perceptions be altered?

Unfortunately, this portrait suggests that those for whom the major barriers may be the belief that nothing more needs to be done are the least likely to seek additional information through sources such as energy audits. This topic is examined in the following section which identifies factors distinguishing the households who were willing to receive an audit from those who were unwilling to pursue this study's offer of a free energy audit. 


\section{INTEREST IN ENERGY AUDITS - BARRIERS TO BETTER INFORMATION}

The premise of the RCS program and of one of its key components, the home energy audit, has been that households lack information on the remaining opportunities for energy savings in their unit. More specifically, audits have been designed to identify low-cost opportunities to save energy and to perform the (rather complex and time consuming) calculations to determine which energy improvements offer the best, or at least, the economically attractive investments. 1 Overall, audits have also been presented as a vehicle by which household interest in and effort to conserve energy can be enhanced even if the information provided by the audit is not the basis of specific subsequent conservation investments.

Osing data from the study, it is possible to assess the degree to which audits are of interest to households who might benefit from the type of information they provide. Factors related to lack of interest in the audit may also be viewed as potential barriers to conservation investment since they impede obtaining information which may logically represent an important step in the decision to improve home energy efficiency.

All households in our initial survey were offered an energy audit which would be provided by a local utility company under the coordination and auspices of The Urban Institute. There was no charge for the audit. The principal cost of the audit was the time commitment of at least one-member of the household. Since most audits were offered

1. A more detailed discussion of audit procedures in general and those used in this study in particular appears in Section IV. 
during normal working hours (although audit could be conducted early evening or late afternoon to accomodate the household's work schedule) this may have involved loss of paid work time. 2 In addition, households were asked to sign a form indicating their willingmess to have the audit and authorizing release of a duplicate copy for use in this study. (The request for a signed form may have decreased audit willingness by one to two percent of households). Over 57 percent of households in D.C. and 70 percent of households in Denver signed the request form. -

We have examined the relationship of a wide range of factors related to this indicator of audit interest (signed a request form) and the results of this analysis are presented in Table II-1. Characteristics of particular interest or which had a significant relationship are showa in Part A of the table. Part B lists factors that were not related to audit interest.

Among demographic factors, audit interest is higher among higher income and more highly educated households. However, income differences are not large or statistically significant. Education is significant at only the .1 level. There is a percentage difference of 11 points between those with high school or less versus post-high school education. Owner and renter households were not significantly different

2. Information gathered during the baseline interview on whether one or more adults were typically home during day time hours did not appear related to willingmess to have the audit, however.

In D.C. a limited number of Saturday audit time slots were available but this did not appear to increase the willingness of households to have an audit. Only 6 Saturday audits were completed.

In Denver, Saturday audits were not available for the study and this did seem to have a dampening effect on audit completions. No systematic evidence is available on this effect, however. 
TABISE II-1

CRARACTERISTICS OR HOUSEMOLDS REQUESTING A FRER ENERCT AUDIT

Part A: Nocable Charactariatics of Housabolda With Audit Requescs

\begin{tabular}{|c|c|c|}
\hline $\begin{array}{l}\text { Characesiseics of } \\
\text { Houschold and Onit }\end{array}$ & $\begin{array}{l}\text { D.C. } \\
\text { Proportion } \\
\text { and/or } \\
\text { Yean }\end{array}$ & $\begin{array}{l}\text { Denyer } \\
\text { Proportion } \\
\text { and/or } \\
\text { Mean }\end{array}$ \\
\hline Encire Suple & 577 & 702 \\
\hline
\end{tabular}

Socio-derographic Characeristics

\begin{tabular}{|c|c|c|c|}
\hline Incones & $\begin{array}{l}\text { Lese than } \$ 15,000 \\
\text { More than } \$ 15,000\end{array}$ & $\begin{array}{l}507 \\
597\end{array}$ & $\begin{array}{l}692 \\
752\end{array}$ \\
\hline Mean $\$ 1,000$ & $\begin{array}{l}\text { With Requese } \\
\text { Wiekouc Request }\end{array}$ & $\begin{array}{l}(\$ 27.0) \\
(\$ 24.0)\end{array}$ & $\begin{array}{l}\$(20.4) \\
\$(18.8)\end{array}$ \\
\hline Edueatiou & $\begin{array}{l}\text { Less throm Eigh School } \\
\text { Bigh School or More }\end{array}$ & $\begin{array}{l}487 * * \\
597\end{array}$ & $\begin{array}{l}665 * \\
757\end{array}$ \\
\hline
\end{tabular}

Yans ac Current genidences

$\begin{array}{lll}0-6 & 787 * 10 & 857 * 0 \\ 7 \text { to } 20 \text { years } & 597 & 667\end{array}$

20 and over $\quad 442 \quad 572$

Life eyele

Youns, wo children

Adules with Children

$757+6$

Over 60, w Children

602

332

$967 \%$

757

Tenure Orraer

$55 \pi$

517

Reaters

737

707

Conserration Activity

\begin{tabular}{|c|c|c|}
\hline $\begin{array}{l}\text { Type of Activity Over Ienure } \\
\text { None } \\
\text { Cueback Oaly } \\
\text { Efficiency Improvemencs Only } \\
\text { Both Cucbecks and Efficiency } \\
\text { Improvemencs }\end{array}$ & $\begin{array}{l}387 \\
462 \\
487 \\
607\end{array}$ & $\begin{array}{l}637 \\
757 \\
697 \\
727\end{array}$ \\
\hline $\begin{array}{l}\text { Major Activiey Siace Moving In } \\
\text { Gigh Leval } \\
\text { Low Level }\end{array}$ & $\begin{array}{l}52 \pi \\
602\end{array}$ & $\begin{array}{l}657^{\star} \\
75 \pi\end{array}$ \\
\hline $\begin{array}{l}\text { Any Hajor Activity in Lase } \\
\text { Mrree-7ests-5ose } \\
\text { Mo Activiey }\end{array}$ & $\begin{array}{l}927^{*} \\
692\end{array}$ & $\begin{array}{l}782^{*} \\
682\end{array}$ \\
\hline $\begin{array}{l}\text { Identity Improvements Still } \\
\text { Needed }\end{array}$ & $58 \pi *$ & $787 *$ \\
\hline $\begin{array}{l}\text { No Improvements Neaded } \\
\text { Plan to Maks Improvements Soon } \\
\text { Do Not Plan Improvements }\end{array}$ & $\begin{array}{l}482 \\
667 * t \\
487\end{array}$ & $\begin{array}{l}517 \\
787 \\
662\end{array}$ \\
\hline $\begin{array}{l}\text { Planned Improvemeats to be Self } \\
\text { Installed }\end{array}$ & $70 z$ & $81 \%$ \\
\hline To Be Inacalled by Contractor & $64 \pi$ & 61\% \\
\hline
\end{tabular}


TABLE II-1 (continued)

\section{Conservation Characteriaties of Jnit}

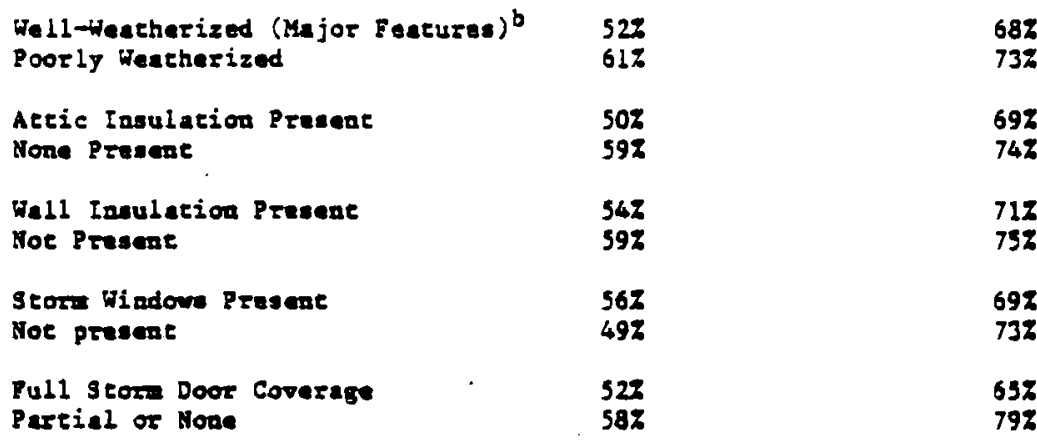

\section{Atritudionl Gheracteriatics}

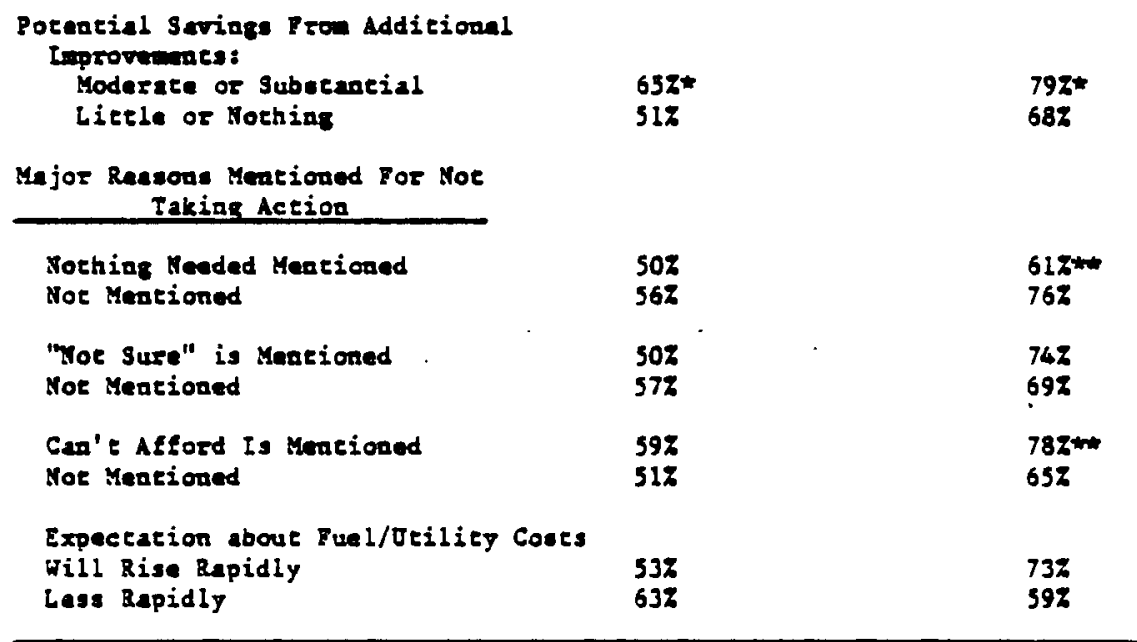

Part B: Other Eacsors Not Simificant ly Belated to Audit Requese

\section{Lise of Factors}

1. Ead heard of Eaergy Audis previoushy

2. Attifudes with regard to temperature seteing and health

3. Respondent repores house is drafty

4. Fuel expe (in D.C., ges versus oil heated)

3. Houschold closes offt roosen in vinens to save on hene

6. Race of respondent (White, Black in D.C.; White, Hispanic in Denver)

7. Type of unit - detached of row house

8. Construction meerial

9. Size of unit (t of soous)

10. Value of home

11. Sex of respoudene

- Sigrificane differeace ac .l lavel.

* Significane differeace at .0s level.

a - Percentages Eor planned improvemeats are based only on proportion of sample tho say some mojor improvement is still aeeded.

b - Weacherization status is besed on presence of four major feacuras as indiceted by respondene - including atric and wall ingulation, storm window and door coverage. 
in audit interest although it is surprising to find that renters accepted audits at high rates. ${ }^{3}$

The most striking and significant differences in audit interest appear with tenure duration and life cycle attributes of households. Interest in the audit drops off sharply among those households with longer tenure and those with adults over age 60 without children.

The second part of the table relates conservation activity measures (both past and planned) to audit interest. Differences in audit interest are relatively weak or inconsistent between sites for measures of past activities. However, households who can identify any improvements still needed in their unit or who say improvements are planned are more likely to request the audit.

There are no significant differences among households requesting the audit based on dwelling unit thermal status (as measured by presence of major features) although there appears to be a tendency for greater audit interest among units with fewer major features in place.

The third section in part A of Table II-1 relates measures of respondents' assessment of potential savings from additional investment, the three mojor reasons for not undertaking actions, and expectations about future costs to audit interest. Those believing substantial

3. Evidence from utility company data shows that renter households request audits less frequently than homeowners. See Hempel, Robert F. and Owens, Ronald L. "Burden Allocation and Electric Utility Rate Structure Options" (Paper presented at Brookings Conference on High Energy Costs, October 1980) for data from the T.V.A. program. Renter audit interest in our sample may be accounted for by the fact that they are more like homeowners (live in one or two rent buildings) than are all renters, the audit was free, and our baseline interview explained that the audit also provided low-cost tips appropriate for renter households. 
savings are possible are wuch more likely to request the audit, while those mentioning that nothing more is needed are less likely to request it (significant in Denver only). Future cost expectations appear to have no consistent or significant effect.

Among other factors ( 1 isted in Part B), it is important to note that familiarity with audits (had heard of audit's being offered by utility companies), size of the unit (proxy for space heating demand) and fuel type (gas versus oil heated in D.C.) did not appear to be significantly related to audit interest. The patterns evident from data in Table II-1 tend to be consistent with those from previous reviews of the utility audit programs in one major respect-audits are sought by those already planning or motivated (predisposed) to undertake activity.

Our findings support only a slight sociomeconomic bias in audit interest. However they reveal significant effects of tenure duration and life cycle which has not been strongly noted in previous research. 4

In order to assess relative importance of these factors (other than audit predisposition), we estimated a regression equation for each sample which incorporated selected demographic and past activity variables and the reasons cited for not making further investments. Results are presented in Table II- 2 .

4. Reviews of utility audit programs have generally cited three apparent biases in the characteristics of households requesting audits (they are homeowners, of higher socio-economic status, and are already planning major conservation improvements). See Dubinsky, Robert, Technical Memorandum \#1, op. cit., and Hirst, E. and Lazarre, P., Evaluation of a Computerized Home energy Audit Program, Minnesota, June 1980. 
CABLE II-2

MULTLLE REGRESSION FOR PREDICFING REQUEST FOR FRES EIARGT AODIT"

\begin{tabular}{|c|c|c|}
\hline $\begin{array}{l}\text { Su. any Statistical } \\
\text { Iadependent Variables }\end{array}$ & D.C. & Demver \\
\hline $\mathbf{B}^{2}$ & .12 & .10 \\
\hline F Eneio & 4.33 & 4.2 \\
\hline Coasent & .78 & .48 \\
\hline Tears at Curterte Reaidence & $=.003$ & $-.007 t$ \\
\hline Lifa grela $2^{b}$ & -.16 & -.05 \\
\hline Life syele $3^{c}$ & $-.37 w$ & -.26 \\
\hline Eouschold Iacon & -.003 & -.002 \\
\hline Eduention & $.016 \mathrm{t}$ & $.03+$ \\
\hline Pact Effores to Curteil Uad & .06 & .07 \\
\hline Nuber of Major Feacures ia-place & -.01 & -.04 \\
\hline Can'i afford Is Major Reason" & -.08 & -.02 \\
\hline "Wot Sure" is Major Reason" & .07 & -.03 \\
\hline $\begin{array}{l}\text { Nunber of Major Actions by } \\
\text { Residene Since Moviag Ia }\end{array}$ & -.006 & .00 \\
\hline
\end{tabular}

- Variable is sigaificane wieh 7 ratio of 3.0 or higher.

t Variable is sigaficant rite $P$ ratio of 5.0 or higher.

a - Dependene veriable is coded ' 1 ' if respondene signed request

for audit (this is distiace froa receipt of audie discussed in Soction

III of the papar), ' $O$ ' if noe. Botnowars oaly are iacluded in regression.

b - Lifecycle 2 is coded ' 1 ' if housebold has adults becreen ages 33 and 60 and children; ' $O$ ' if otberwise.

$c$ - Lifecyele 3 is coded ' $l$ ' if only parsons is housahold adules over 60; ' 0 ' if otherwise.

d - Variable for cureail use is coded ' $I$ ' if one or more specific effores are reported; ' $O$ ' if noue.

- Reason veriable are based oa open-eaded reepones to questioa about injor reasone for not making additional energ efficiency inprovements. Coded ' $l$ ' if chis resposse is mancioned; ' $O$ ' if aot. 
The results of this analysis are important in three respects. While statistically significant, these equations amount for only a small portion of the variance in audit interest. $\left(R^{2}=.12\right.$ and .10 in D.C. and Denver respectively). Thus, demographic factors (even if correlated with the predisposition factors which are omitted) do not well explain audit interest. However, it does appear that the more highly educated are likely to request the audit (those who may need it less). Years at zurrent residence or life cycle do appear significant in at least one equation with expected negative effects.

Secondly, interest in audits is not significantly related either to the major features in place or to the number of major conservation improvements previously installed. (These items were entered separately in equations not reported and the individual effects were insignificant as well). This result suggests there is no bias toward inefficiently providing audits only to households already well insulated. This concern has been frequently expressed by utility companies, and others critical of audit programs. However the data also indicated that less well insulated homes are no more likely to be audited.5 Thirdly, households who say that "uncertainty about what to do" is the prime obstacle to further investment are no more likely to take advantage of an audit than are others. Thus, households whom we might expect to most want an audit because they lack the information it can provide do not respond well to a free offer of relevant information. This finding casts doubt on the importance of this obstacle to conservation

5. See Residential Conservation Service Program - Regulatory Analysis, U.S. Dept. of Energy, October, 1979. DOE-CS-0010411. 
investment. Perhaps the response simply disguises a general unwillingness to pursue conservation opportunities.

Overall, the analysis of audit interest among households in our study is not strongly supportive of the potential of audits to stimulate conservation activity among households who may most need some additional stimulus to undertake further low cost or major conservation actions. While the socio-economic bias evident in other reviews of existing utility audit programs does not appear as strong in this data, a predisposition toward conservation action (improvements already planned) seems to be the strongest correlate of household interest in an audit. 6 This result offers support to the sumary picture portrayed in the previous section, that the greatest obstacle to further investment in energy efficiency is absence of perceived potential for additional energy savings.

6. These factors will be assessed in greater detail in the final report. 
III. THE PAYBACR TO CONSERVATION INVESTMENT: HOUSEHOLD EXPERIENCES AND EXPECTATIONS

Energy audits provided by utilities under the RCS program offer detailed information on the costs of various conservation improvements and projected annal fuel/utility savings which would result from each option. A major component of the audit report to the household includes an estimated annual payback period (cost divided by savings) for each item based on the cost and savings calculations. The sophisticated user can presumably use such information for identifying the items that are most cost effective to install (given the unit's current thermal efficiency and household energy consumption).

Despite the sophisticated analysis embodied in the audit, there is little available evidence concerning the level of payback households might require before undertaking additional conservation investment or even whether households use such information in making decisions to improve their home. The payback period implies a rate of return on investment which households might heavily discount. The future stream of (annual) savings may not be attractive in light of high initial costs associated with many conservation items.

How required rates of return and related discount factors vary with household characteristics are questions without firm answers. The general consensus, however, is that the rates of return required and the discount rates applied by households are extraordinarily high - which simply means that households do not readily undertake conservation 
improvements with rates of return which would normally be considered attractive opportunities in other investment areas. 1

Pursuing a much less sophisticated economic analysis, we can utilize data from our baseline survey to describe one version of payback on conservation items implied by the conservation expenditures and energy savings reported by sample households. Implied paybacks can be estimated both for past expenditures on conservation improvements-primarily attic or wall insulation, storm windows or doors and combinations thereof-and for a range of planned future investments. Savings estimates are unfortunately crude and approximate, reflecting, however, respondents estimates of how much their monthly energy bills have been or will be reduced by the conservation improvements with which they are familiar .

Table III-1 presents the distribution of estimates of monthly savings. Three sources of savings are identified: those from past improvements, those expected from future improvements, and those derived from curtailment in energy use-a measure which is presented for comparison. The table also indicates the proportion of the samples for whom the particular source of savings was not utilized and the proportion who

1. Two recent studies-one of consumer behavior with regard to airconditioner purchase and use and the other with regard to refrigerator pricing both imply relatively high discount rates. J. A. Hausman in Individual Discount Rates and the Purchase and Use of Energy Using Durables Bell J. of Economics, Vol. 10, No. 1. PP 33 to 54 finds that implied discount rates decline sharply with annual income class from 897 at $\$ 6,000$ or less to 5.17 at $\$ 50,000$ or more. D. Gately, in Comment on Housman's article in the same journal Vol. 11, \#1 pp. 373-374 finds discount rates implied by differential pricing of more efficient and less efficient refrigerators to be between $45 \%$ and $300 \%$. 
TABLE III-1

ROUSEHOLDS' PAST AND EXPECTED SAVLNGS FROM ENERGY CONSERVATION

\begin{tabular}{|c|c|c|c|c|}
\hline \multirow[b]{2}{*}{$\begin{array}{c}\text { Source of } \\
\text { Sevings }\end{array}$} & \multicolumn{2}{|c|}{ D.C. } & \multicolumn{2}{|c|}{ Denver } \\
\hline & $\begin{array}{l}\text { Encire } \\
\text { Sample }\end{array}$ & $\begin{array}{c}\text { Mose } \\
\text { Accive" }\end{array}$ & $\begin{array}{l}\text { Eacire } \\
\text { Sample }\end{array}$ & $\begin{array}{c}\text { Hosc } \\
\text { Activea }\end{array}$ \\
\hline 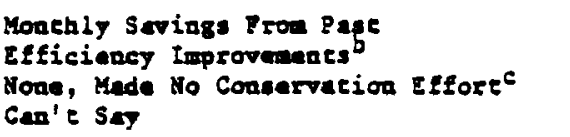 & $\begin{array}{l}292 \\
197\end{array}$ & & $\begin{array}{l}262 \\
122\end{array}$ & \\
\hline 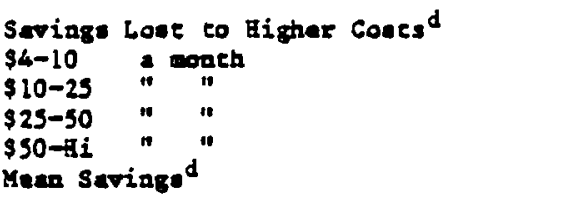 & $\begin{array}{r}702 \\
61 \\
112 \\
62 \\
72 \\
943\end{array}$ & $\begin{array}{r}772 \\
32 \\
102 \\
52 \\
52 \\
\$ 43\end{array}$ & $\begin{array}{r}672 \\
142 \\
122 \\
52 \\
22 \\
\$ 21\end{array}$ & $\begin{array}{r}682 \\
97 \\
197 \\
42 \\
47 \\
\$ 26\end{array}$ \\
\hline $\begin{array}{l}\text { Moathly Savinge Pron Pase } \\
\text { gfforte to Cutbeck on Jaeb } \\
\text { Noae, Did wot Curbacke } \\
\text { Can'e Say }\end{array}$ & $\begin{array}{l}302 \\
122\end{array}$ & & $\begin{array}{r}332 \\
92\end{array}$ & \\
\hline 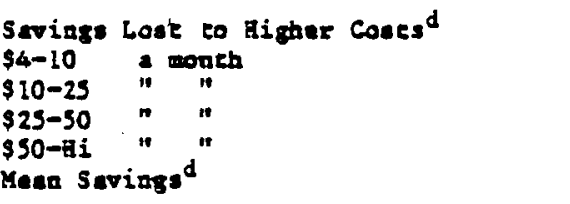 & $\begin{array}{r}712 \\
82 \\
132 \\
62 \\
22 \\
\$ 29\end{array}$ & $\begin{array}{r}722 \\
92 \\
112 \\
42 \\
42 \\
\$ 34\end{array}$ & $\begin{array}{r}762 \\
112 \\
102 \\
32 \\
02 \\
\$ 17\end{array}$ & $\begin{array}{r}772 \\
102 \\
72 \\
62 \\
02 \\
\$ 11\end{array}$ \\
\hline $\begin{array}{l}\text { Expected Monchly Savings } \\
\text { Frod P lanned Efficiency Improvements' } \\
\text { None Planned e } \\
\text { Can'e Say }\end{array}$ & $\begin{array}{l}602 \\
122\end{array}$ & . & $\begin{array}{r}672 \\
87\end{array}$ & \\
\hline 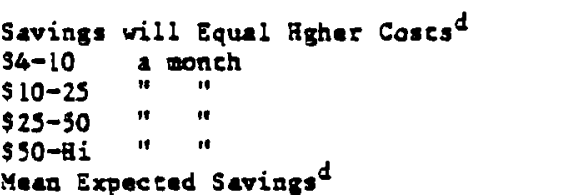 & $\begin{array}{l}232 \\
212 \\
252 \\
192 \\
128 \\
\$ 33\end{array}$ & $\begin{array}{r}262 \\
202 \\
322 \\
162 \\
72 \\
\$ 27\end{array}$ & $\begin{array}{r}397 \\
267 \\
217 \\
107 \\
57 \\
\$ 21\end{array}$ & $\begin{array}{r}478 \\
267 \\
428 \\
37 \\
37 \\
\$ 19\end{array}$ \\
\hline
\end{tabular}

a - Most active mensure is based on aumber of four major efficiency improvemencs installed during cenure.

b - Monchly sevings are respondene answers with respece to direce quescions on gavings from pest efficiency improvemats, frow past efforts to curtail use, and gavings expected frow planned efficinacy improvemencs (before naxe vinter) which respoadeat identifies.

c - Show percencage of sample who gay ao conservacion effore of that sppe coupleted (or planned).

d - Percentages besed on proportion of sample who experienced sose savings. Excludes "can't say" an vell.

- Masn based ouly on ehose mentioniag a dollar savings. 
could not provide an estimate of savings despite having made or being about to make efforts at energy conservation.

Perusal of the table indicates that 10 to 20 percent of households who have made or plan some conservation effort are not able to venture a guess at experienced or expected savings. With respect to past savings from investments or curtailments, 68 to 77 percent of households (both among the active and the entire samples) report that savings have been lost to higher energy prices. (Although far more households report not cutting back than report no efficiency improvements.) Clearly, the dominant return to conservation effort for households has been one of "offsetting" energy bill increases rather than achieving actual reductions in existing levels of costs. Estimates of net reductions to bills that are reported range from $\$ 4$ to $\$ 50$ per month for past efforts with a typical modal savings of $\$ 10$ to $\$ 25$. Average saving (from among those reporting net reduction) ranges from $\$ 11$ to $\$ 43$ with D.C. residents consistently reporting higher average savings. It is also noteworthy that in all instances there are fewer and lower average reported returns to curtailment of energy use than from efficiency improvements.

Expectations about savings from improvements which are planned are more optomistic in that smaller proportions expect savings to be immediately offset by higher costs (although this proportion is from among only about $30 z$ of households planning improvements). The mean expected net monthly savings range from $\$ 19$ among Denver households who were active in making past improvements to $\$ 33$ among the entire D.C. 
sample. In sumary, it appears that only a small proportion of households (even among activists) attempt to identify savings with specific accuracy and there is apparent consistency across questions and sites in responding to our query about savings. This suggests that conservation effort is mostly an effort to hold the line on costs rather than a sophisticated optimising strategy. ${ }^{2}$

Table III-2 presents measures of payback (in months) for past and planned investments by households at both sites by utilizing data where net savings and estimated costa of past or future conservation improvements were available. Average montbly paybacks range from 26 to 59 months.

The table also presents information on the distribution of the average length of payback for various demographic and conservation activity characteristics of the sample. The very small sample sizes which result from this breakdown and widely varying payback distribution results in few statistically significant relationships. Two relationships do lend support to the inherent meaning of the payback measures, however. Households who reported in a separate survey question that "substantial savings" from future savings were possible show consistently shorter payback experiences and expectations than do households reporting that they believe "little savings" are possible: In Denver, where the survey obtained an assessment of whether savings from past investments were "more, less, or about as expected" there is evidence

2. The response code, "savings lost," to higher costs was not an optional answer mentioned in the question. Rather, variants of this answer were so frequent we coded our response categories after survey pre-testing to accomodate this response. 
IABLE III-2

DISTRIBOTION OR PAYBACK PERIODS FOR PAST AND EUTURE EFFICIENCY INVSTMENTS

\begin{tabular}{|c|c|c|c|c|}
\hline \multirow[b]{2}{*}{$\begin{array}{l}\text { Charzetaristics } \\
\text { of Divlling Daits/ } \\
\text { Bowechold. }\end{array}$} & \multicolumn{2}{|c|}{ D.C. } & \multicolumn{2}{|c|}{ Denver } \\
\hline & $\begin{array}{l}\text { Monthly } \\
\text { Payback } \\
\text { From Pasee } \\
\text { Investments }\end{array}$ & $\begin{array}{l}\text { Monebly } \\
\text { Paybeck } \\
\text { From Plauned } \\
\text { Inves cmenes }\end{array}$ & $\begin{array}{l}\text { Monchly } \\
\text { Payback } \\
\text { Pron Pase } \\
\text { Invescones }\end{array}$ & $\begin{array}{l}\text { Monehly } \\
\text { Payback } \\
\text { Irou Plamed } \\
\text { Inveschones }\end{array}$ \\
\hline Entire Semple & 43 & 59 & 58 & 25 \\
\hline $\begin{array}{l}\text { Mousehold Ineowe } \\
\text { Less than } \$ 15,000 \\
\text { Mote than } \$ 15,000\end{array}$ & $\begin{array}{r}29 \\
49\end{array}$ & $\begin{array}{l}62 \\
60\end{array}$ & $\begin{array}{l}84 \\
49\end{array}$ & $\begin{array}{l}25 \\
26\end{array}$ \\
\hline $\begin{array}{l}\text { Education: } \\
\text { Less than High School } \\
\text { High School or More }\end{array}$ & $\begin{array}{l}21 \\
50\end{array}$ & $\begin{array}{l}52 \\
63\end{array}$ & $\begin{array}{l}78 \\
44\end{array}$ & $\begin{array}{l}18 \\
29\end{array}$ \\
\hline $\begin{array}{l}\text { Lifecrele: Young, wo } \\
\text { Children } \\
\text { Wich children } \\
\text { Older, wo ebildren }\end{array}$ & $\begin{array}{l}- \\
48\end{array}$ & $\begin{array}{l}56 \\
56 \\
104\end{array}$ & $\begin{array}{l}38 \\
58 \\
77\end{array}$ & $\begin{array}{l}28 \\
24 \\
\mathrm{in}\end{array}$ \\
\hline $\begin{array}{l}\text { Major Conservation Activity } \\
\text { Active } \\
\text { Less Active. }\end{array}$ & $\begin{array}{l}52 \\
14\end{array}$ & $\begin{array}{l}41 \\
73\end{array}$ & $\begin{array}{l}79^{* 6} \\
30\end{array}$ & $\begin{array}{l}39^{*+} \\
20\end{array}$ \\
\hline $\begin{array}{l}\text { Proportion of I tewis in Place } \\
\text { Iascalled by. Current Occupane } \\
\text { High } \\
\text { Low }\end{array}$ & $\begin{array}{l}45 \\
26\end{array}$ & $\begin{array}{l}69 \\
52\end{array}$ & $\begin{array}{l}60 \\
51\end{array}$ & $\begin{array}{l}33^{*} \\
20\end{array}$ \\
\hline $\begin{array}{l}\text { Aeticudial } \text { Gharaceeriscies } \\
\text { Expect Future Eaergy } \\
\text { Coses to Rise Rapidiy } \\
\text { Rise More Slouly }\end{array}$ & $\underline{-}$ & $\begin{array}{l}67 \\
51\end{array}$ & $\overline{-}$ & $\begin{array}{l}26 \\
21\end{array}$ \\
\hline $\begin{array}{l}\text { Reasons for not making } \\
\text { additional improvements: } \\
\text { "Not sura what to do" is important } \\
\text { not important }\end{array}$ & $\begin{array}{l}17 \\
45\end{array}$ & $\begin{array}{l}88^{*-} \\
46\end{array}$ & $\begin{array}{l}38 \\
63\end{array}$ & $\begin{array}{l}17 \\
30\end{array}$ \\
\hline $\begin{array}{l}\text { "Would not save enough" is important } \\
\text { not important }\end{array}$ & $\begin{array}{l}75^{*} \\
32\end{array}$ & $\begin{array}{l}73 \\
51\end{array}$ & $\begin{array}{l}49 \\
60\end{array}$ & $\begin{array}{l}27 \\
29\end{array}$ \\
\hline $\begin{array}{l}\text { "Can'e Afford" is importane } \\
\text { not important }\end{array}$ & $\begin{array}{l}45 \\
40\end{array}$ & $\begin{array}{l}58 \\
61\end{array}$ & $\begin{array}{l}49 \\
63\end{array}$ & $\begin{array}{l}24 \\
26\end{array}$ \\
\hline $\begin{array}{l}\text { Savings Potential Erow Invescment } \\
\text { Moderate to Substantial } \\
\text { LiEtle of nothing }\end{array}$ & $\begin{array}{l}28 * \\
70\end{array}$ & $\begin{array}{l}56 \\
72\end{array}$ & $\begin{array}{l}49 \\
66\end{array}$ & $\begin{array}{l}23 \\
29\end{array}$ \\
\hline $\begin{array}{l}\text { Savings Frow Pase Invesements Here: } \\
\text { More than Expectad } \\
\text { About as Expected } \\
\text { Lass than Expected }\end{array}$ & $\bar{z}$ & $\bar{z}$ & $\begin{array}{r}36^{\text {tw }} \\
48 \\
122\end{array}$ & $\begin{array}{l}13 \\
26 \\
28\end{array}$ \\
\hline $\begin{array}{l}\text { Current Conservacion Scatus } \\
\text { Well weacherized } \\
\text { Poorly wastherized }\end{array}$ & $\begin{array}{l}47 \\
25\end{array}$ & $\begin{array}{l}54 \\
65\end{array}$ & $\begin{array}{l}75^{\text {*t }} \\
16\end{array}$ & $\begin{array}{l}23 \\
28\end{array}$ \\
\hline
\end{tabular}


that the average length of payback accords with this assessment of past investments.

Table III-3 provides additional information on relationships among payback durations. The length of payback is highly related to size of investment, indicating that households who make large conservation expenditures expect to wait longer to fully realize their return on investment. There appears to be no significant relationship, however, between payback period experienced from past investments with that expected from future investments. (This correlation is based on only about 107 of the samples for whom past and expected payback measure were available.)

This information on payback experience and expectation can offer only limited evidence about the rate of returna households require before undertaking investments. In addition, to interpret these findings as annual payback requirements necessitates some translation from the monthly terms in which this information was gathered. Most references to energy savings during the course of our interview were in relation to winter heating costs. Because these savings estimates are probably associated with only the heaviest heating and (perhaps) peak cooling months, we cannot assume that full savings are realized over all twelve months of the year. Using six months ( $1 / 2$ year) as an appproximation of the period over which savings are realized would suggest that past average paybacks would be from 7 to 10 years. On the same basis, future payback expectations would range from 4 to 10 years (if savings accured only from net reductions). However, without extensive 
TABLE III-3

RELATIONSHIPS AMONG INVESTMENT COSTS

AND LENGTH OF PAYBACK

\begin{tabular}{llc}
\hline Items Correlated & D.C. & Denver \\
\hline $\begin{array}{l}\text { Total Previous Investment } \\
\text { With Length of Payback }\end{array}$ & $.62+$ & $.78++$ \\
$\begin{array}{l}\text { Total Planned Investment } \\
\text { With Expected Length }\end{array}$ & $.29+$ & \\
of Payback & & \\
$\begin{array}{l}\text { Length of Payback from Past } \\
\text { Investment With Length of } \\
\text { Payback Expected for Planned } \\
\text { Investment }\end{array}$ & -.18 & .06 \\
\end{tabular}

+ Significant at .05 or better.

a - Correlations are'Pearson's R.

b - Total investments are summed dollar figures

provided by respondent for costs of various past investments (attic, wall insulation, storm doors) or total expected expend itures. 
information on fuel price increases over the relevant time period, it is difficult to estimate the total savings involved. ${ }^{3}$

In summary, while our data can only be used as the bases for speculation, it appears that even among households who have had experience with or are planning efficiency improvements, most do not use-or at least cannot articulate-a sophisticated economic calculus for their investment decisions. Energy price changes would appear to be the confounding factor. 4 Most households perhaps decided to make improvements to limit increases in fuel bills in the face of great uncertainty about future prices. Among households who do report net reduction in bills, paybacks have falled typically within the 10 year or less range that is the key focus for conservation items evaluated by RCs audits.

3. It is possible that for past investments, households "made a mistake"-i.e. did not receive a rate of return they wanted or expected. The only evidence we can bring to bear on this would not support such an interpretation. Over 60 percent of the Denver sample said they saved about what they expected to, or more, while of 40 percent (who said they saved less or didn't know) most say that expected savings were lost to unexpected increases in energy prices. 4. Utilities also find it difficult to project future price paths-information which, from an investment perspective, is essential to evsluating any choices with paybacks of a few years or more. Audit evaluation frequently use only current prices or flat projected rate of increase as the basis of the savings estimates. 
IV. THE POTENTIAL FOR INCREASED ENERGY EFFICIENCY: A COMPARISON OF HOUSEHOLD PERCEPTIONS AND AUDIT RECOMENDATIONS

\section{Overview}

This section provides wore detailed information on the energy audits provided to households in this study. Then, utilizing data from both the audit results and the information from the baseline survey, we provide a detailed assessment of the degree of correspondence between households' perception of needed conservation improvements and the paybacks (rates of return) estimated for those items by the audit. While some error in audits undoubtedly exist, we will presume that the audit data is the "correct" identification of remaining conservation potential for the unit.1 This analysis may be viewed as assessment of the sophistication in households' knowledge about conservation opportunities. Viewed from a different perspective, the analysis offers an assessment of the degree to which audits can supply additional or more accurate information to households who are unaware of-or mistaken about-the remaining options. ${ }^{2}$

\footnotetext{
1. Audit "error," the degree to which it does not accurately portray conservation opportunities for the unit, may be found in three sources. The first is imprecision in input measurements by the auditor or in the consumption data for the household. Consumption data based on utility records or computor estimates are the basis against which reductions in heat loss or gain in percentages tenure are applied. The second source of error may be found in the parameters of the models used to estimate heat loss and reductions in heat loss that result from thermal improvements. The third source of error is in the cost of materials and work (contractor or self-installed) which represent geographic area averages and may be out of date. In addition, it is likely that individual households will obtain materials or services that vary substantially around the averages used by the auditor.

2. An evaluation of audit effectiveness in altering respondent awareness of available options will be included in the subsequent project report.
} 


\section{Audit Measures of Energy Savings}

Energy audits have been developed to provide detailed information on the remaining energy saving potential from additional investment in residential retrofit (or reveal that units have exploited all economically attractive measures). As designed and conducted by many private firms, numerous state agencies and a majority of utility companies, the two most notable features of the audit are:

- An on-site inspection of the major thermal features in-place and of less obvious points of heating, cooling system or thermal shell inefficiencies.

- An evaluation of the economic attractiveness of each of several specific options for weatherization improvement. The evaluation reflects the current heating/cooling requirements and energy use habits of the household. In addition to specifying cost and savings that may result from new features, the audit can show where improvements in existing features are appropriate.

The value of the on-site inspection is that trained auditors are equipped to quickly and easily obtain the information on factors central to the evaluation. These include space and volume measurements for the unit and for key components such as window areas; measurement and inspection of installed insulation; and characterization of the inherent insulation of the building structural material. Judgements about feasibility of installation of insulation in outside walls or attic crawl space, for instance, are also made during the inspection.

While audit results from different organizations might differ somewhat depending on cost and savings parameters in the model, audits have achieved a remarkable degree of consistency and provide information 
that may be particularly costly or time consuming for homeowners to obtain on their own. ${ }^{3}$

Three utility companies provided audits of a subset of our sample households. While variations in audit procedures and presentation of results were evident among the utilities, we belief that the audit data derived from the on-site inspections are reasonably comparable and can be used as a single source of information. 4

The items covered in the audit evaluations include the major features we have referenced throughout this report including attic and wall insulation, storm windows and doors. Other forms of insulation (primarily floor/crawl space), water heater insulation, caulking/weatherstripping, and installation of clock thermostats were the additional major items evaluated by the audits. These items are the common major features used in the following analysis. 5

3. Audit evaluations differ in the detail provided on costs of weatherization features. At a minimum, they provide an estimate of typical contractor installation covering labor and materials. These may be presented as mean or median cost estimates obtained from a survey of local suppliers. Some audits also show costs of materials alone for items typically self-installed, such as attic insulation or storm windows. Self-installed costs were not provided in one of the three utility audit formats in this study.

4. We accompanied auditors on several occasions to observe the procedures followed in the household. A more detailed discussion of audit procedures is provided in a background report. The appendix to this paper presents a comparison of selected audit savings estimates and sample result forms from the audits that were provided both to the participating household and to this study as a source of data.

5. Audits may also consider the feasibility of solar hot water and space heating, solar swimming pool and green house, and wind generation for electricity needs. Evaluation of these items in our sample was available only in Denver and consequently these items are not included in our analysis. 
Sample Bias in Characteristics of Households Receiving Audits

As part of the study, approximaely 25 percent of the sample households received a free energy audit. Because households selfselected for the audit (by signing a request form) and because there was a great deal of variation in the way in which audits were scheduled, there is a possible bias in energy-related characteristics of the subsample which received audits relative to the full baseline sample.

The low-response audit completion rate is a result unintended in . the original study design. We sought audits from 50 percent of households; obtained signed audit requests from 58 percent of survey households; and expected a much lower dropout rate. Asessing the characteristics of households that were audited becomes particularly important given the lower completion rate.

It is important to note that this analysis is distinct from that provided in section II of this report. There we assessed the factors related to requests for audits. About half of those households requesting audits did not complete them. 6

Table IV-1 shows a variety of selected measures of the audited and unaudited households in both sites. The measures cover demographic attributes, past conservation actions and planned activities, current

6. The factors which account for the drop-off between audit request and completion may partially represent respondents' behavior. Some households changed their mind about receiving the audit or could not be reached to schedule an audit. However, our scheduling of the audits and utility company procedures also substantially affected who got an audit. In combination, we believe that several factors tended to randomize the resulting characteristics of the households who were audited. This analysis is directed at identifying any bias in resulting distribution and not at factors which determine who finally received an audit. 
2uthe $\mathbf{r - 1}$

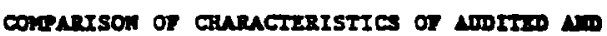

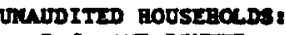

D.C. 4 D Divis

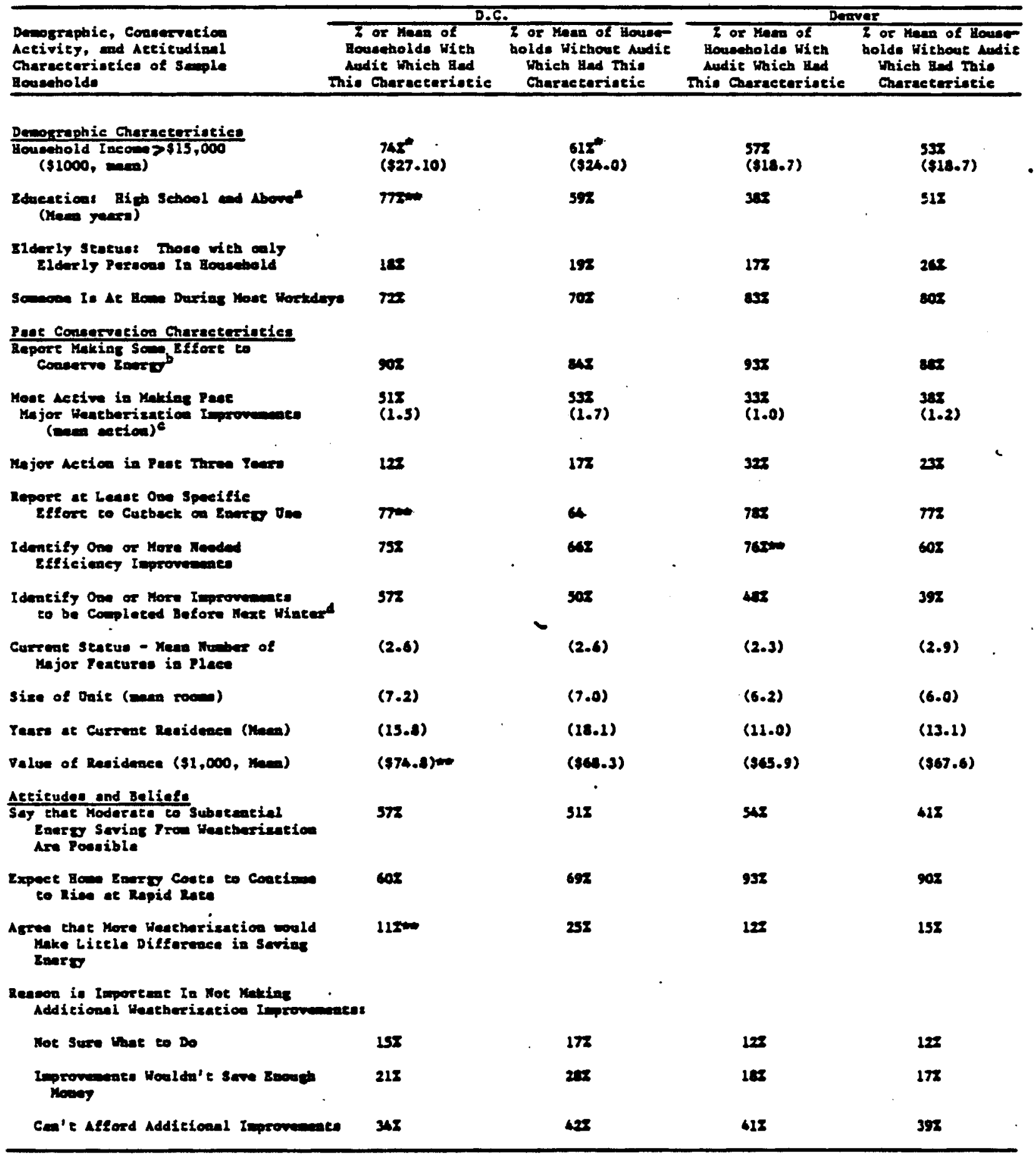

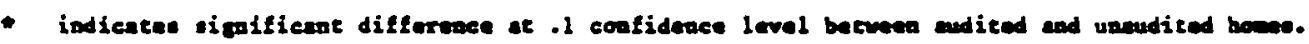

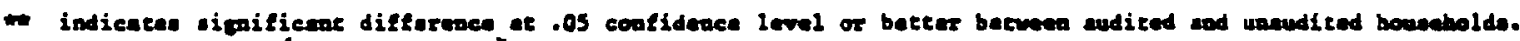

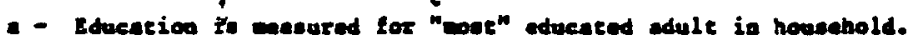

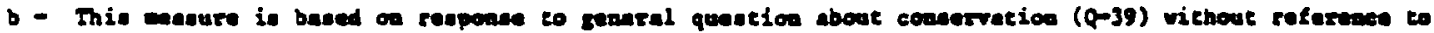

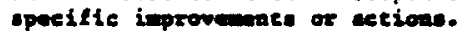

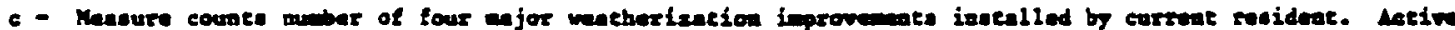
cecegory includes two or sore inprovemess.

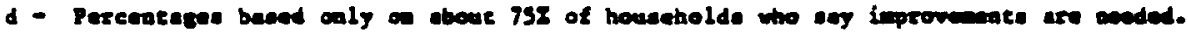


conservation status of the unit, and selected household attitudes and beliefs. Statistically significant differences between audited and unaudited households are noted.

We do find some evidence for bias toward higher socio-economic status of audited households. Audited households are more likely to have higher incomes (significant in D.C.). It appears, however, that we have more highly educated households in D.C. and less highly educated households in Denver within the audit subsample.

Measures of conservation effort do not significantly or systematically differ with the exception of the D.C. audit sample proportion who report curtailments in energy use. There is no difference in status as measured by major features in place. The size of audited dwellng units appears slightly. larger than non-audited units; tenure duration is shorter in both audited subsamples. (These differences are not significant.)

It is important that audited units in both sites were more likely to identify one or more efficiency improvements as needed and to say that such improvements were definitely planned. While only one of these four relationships are statistically significant (at .05), this difference indicates that our audited sample is more likely to be concerned about the need for further improvements and likely to take subsequent actions than is than the unaudited sample. Some attitudinal responses support this picture (although also without consistent statistical significance). Households who believe that moderate to substantial savings from efficiency improvements are possible are more likely to be in the audit sample (by 6 percentage points in D.C. and 13 
percentage points in Denver) and audited households are less likely to agree (significant in D.C.) that weatherization "makes little difference in energy savings."

There are no large, sigaificant or systematic differences in the major reasons cited for not making additional conservation improvements (bottom portion Table IV-1).

Overall, in the following analysis it will be important to keep in mind that we probably have among audited households, those of slightly higher socio-economic status and who are more interested in impending conservation investment (an attitudinal characteristics not based on past activity or current dwelling unit status) and therefore, perhaps more knowledgeable than the full sample about remaining conservation potential in theis units.

\section{The Distribution of "Needed" Improvements}

Table IV-2 provides simple frequency distributions of energy efficiency improvements identified as "needed" by the energy audits and by the households in the audit samples. To define "needed" items by audit standards, we have examined the payback ratios for ech item (contractor installed cost/estimated annual savings) and used 5 years and 10 years paybacks as threshold levels. If the cost of the conservation improvement can be recouped through lowered energy bills in 5 years or less, the item is considered very attractive.

As is evident in the first column for each site, the energy audit identified at least some item from among the six summary categories that provide an attractive ( 5 year or less payback) for nearly all households. Only 3 percent of audited D.C. households and 13 percent of 
TABLS IV-2

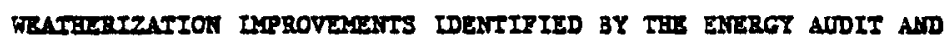
BT BOUSEBOLDS RECEIVIHG AUDITS

\begin{tabular}{|c|c|c|c|c|c|c|}
\hline \multirow{3}{*}{ Couservacion Paneure } & \multicolumn{6}{|c|}{ Proporeion of Audit Households } \\
\hline & \multicolumn{2}{|c|}{$\begin{array}{c}\text { Andil } \\
\text { Recom }\end{array}$} & \multirow[t]{2}{*}{$\begin{array}{l}\text { Identified } \\
\text { br Bounehold }\end{array}$} & \multicolumn{2}{|c|}{$\begin{array}{c}\text { Audit } \\
\text { Becomendation }\end{array}$} & \multirow[t]{2}{*}{$\begin{array}{l}\text { Identified } \\
\text { b) gousehold }\end{array}$} \\
\hline & $\begin{array}{l}\text { Paback } \mathrm{Pa} \\
5 \mathrm{yrs}=10\end{array}$ & $\begin{array}{l}\text { aybuck } \\
\text { yea }\end{array}$ & & $\begin{array}{l}\text { Paybuak } \\
5 \text { yes. } 10\end{array}$ & yorak & \\
\hline Toehing ondede & 38 & $\mathbf{0 z}$ & 258 & 132 & 32 & 232 \\
\hline Inulation (actie, wall or Hoor) & 518 & 792 & 472 & 262 & 832 & 532 \\
\hline Scorz vindow & $0 \mathbf{2}$ & 218 & 427 & 08 & 298 & 398 \\
\hline Seote doors & $\mathbf{0 2}$ & 02 & 218 & 02 & $0 \mathbf{5}$ & 223 \\
\hline Calkịg/wacherseripping & $16 \pi$ & 467 & 267 & 467 & 718 & 228 \\
\hline Invulate piped/hot vater hencer & 882 & 908 & 18 & 417 & 427 & 78 \\
\hline Clock chormoseat & 172 & 172 & 17 & 982 & 682 & $0 \mathbf{8}$ \\
\hline
\end{tabular}

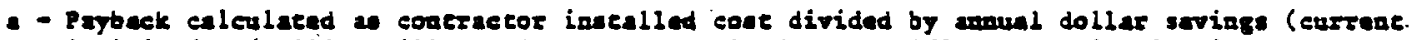

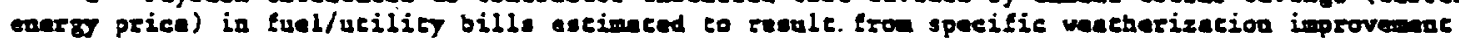
(daca frow adit). Those with sovings greater than $20 \mathrm{z}$ of coats are included (i.e. paybeck is 5 years or lese).

b - As in (a) abow, exeepe amual suvings are 102 or wore of coses (pajbeck is 10 yanx or

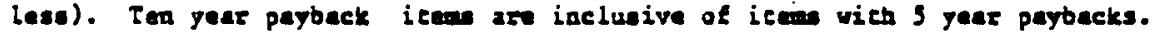

$e$ - "hothing needed" refers co units for wich audie finds no five year (10 yaar) or lese pay back for the six specific item in the table and to household responses which do aot identify any of

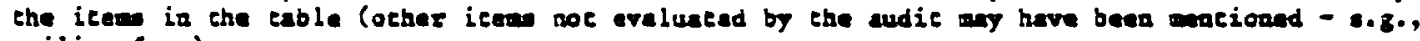
ceiliag (ans). 
Denver households had ao such item. The most common attractive improvement in D.C. is hot water heater or pipe insulation (for $88 \%$ of units) while the most frequent high payback item in Denver is a clock thermostat ( 58 percent). Improved caulking/weatherstripping offers high payback for 16 percent of households in D.C. and 46 percent of households in Denver. Some type of insulation (attic, wall or floor) had five years or less payback for 51 percent of households in D.C. and 25 percent in Denver. 7

The frequency with which units would have paybacks of ten years or less is also shown in the table. 8 No households in D.C. are without at least one 10 year payback option and only 3 opercent of households audited in Denver would have no 10 year payback option. It is particularly noteworthy that the energy audits in both sites found no instances of five year or better payback for installation of storm windows or storm doors despite the fact that many audited households lack coverage of these items.9 On a ten year payback basis, improvements in storm window coverage would offer paybacks to 21 percent and 29 percent of households respectively in D.C. and Denver.

The frequency distribution of items identified as needed by households who were audited is quite different than that recomended by

7. These insulation items were combined (although paybacks were calculated separately) for comparability to our survey coding scheme.

8. Consevation items with five year or less paybacks are, by definition, a subset of items with 10 year or less paybacks.

9. This finding is consistent with the general impression we gained from talking with conservation engineers who indicate that the cost of storm window installation in older homes is so high that it is difficult to achieve an attractive return. The average contractor installed cost for storm windows estimated for Denver by the audits was approximately $\$ 625$; but ranged up to $\$ 3000$. In D.C. the average storm window cost was $\$ 750$ ranging up to $\$ 5800$. 
the audits. This distribution is based on the (up to three) responses by each household to the question "what things do you think (still) could be done to this house to cut down on its use of energy and rake it more efficient?" First, despite the fact that the audit sample may be skewed toward households who are more likely to identify needed items, the response that "nothing more was needed" (25z and $23 \%$ ) is much greater than that implied by the audit.

The proportion of audited households, however, who mentioned insulation (attic, wall or floor) is much closer to the ranges suggested by the audit payback findings. The proportion of households who thought that storm windows or doors could be added (in fact the most frequent responses following insulation) quite markedly exceeds the audit findings.

Attention to the less expensive improvements such as caulking, hot water heater insulation, and clock thermostats is considerably lower than it is to major items. In D.C., households perception of the need for additional caulking/weatherstripping ( 26 percent) falls between the proportion recoumended by the audit under the 5 and 10 year payback criteria. In Denver, households under-estimate the potential of caulking and weatherstripping (22 percent) rather substantially relative to audit recoumendations.10 Hot water heater (and pipe) insulation was identified by only 1 percent and 7 percent of the samples respectively. Clock thermostats apparently have received the attention of

10. This finding is particular noteworthy in Denver, since caulking can be done by a member of the household in many instances and the payback from the audits shown here are based on contractor costs. Thus, the under-estimation of caulking potential in Denver is very 
almost no households as opportunities for energy savings. While setting back thermostat during periods of sleep or absence from the home can be performed manually, the auditors checked this practice with the household. Thus, the evaluation of payback substantially reflects the incremental savings due to automatic setback relative to the current practice of the household.

In summary, Table IV-2 suggests a rather strong mismatch between household and audit estimates of the opportunity for and the source of economically attractive efficiency improvements to the home.

For each household and each conservation item we have defined two types of "error" based on the comparison of conservation options identified by the audits and by our respondents. "Error type $A$ " we attribute to households who do not identify a conservation item as needed but for which the audit has found that the payback would be 5 years or less. "Error type $B$ " we attribute to households who identify an item as needed but for which the audit finds that the payback would be greater than ten years. Generally, speaking, both types of error reflect a lack of knowledge about the most appropriate sources of energy saving improvements.

Table IV-3 provides an indication of the frequency of these types of errors by item for the audited households. The first column shows simply the proportion of households who identify the conservation item as needed out of all households for whom the item offers five year payback. 11 In both sites, households did best in identifying the found no households with 5 year payback on these items. 
TABLE IV-3

ACCURACY OF HOUSEHOLD PERCEPTIONS OR MEEDED CONSERVATIOH IMPROVERENTS

\begin{tabular}{|c|c|c|c|c|c|c|c|}
\hline \multirow[b]{3}{*}{$\begin{array}{l}\text { Efficiency or } \\
\text { Weatherization limprovemente } \\
\text { Evaluated by Audit }\end{array}$} & \multicolumn{7}{|c|}{ Proportion of Householde } \\
\hline & \multicolumn{4}{|c|}{ D.c. } & \multicolumn{3}{|c|}{ Denver } \\
\hline & \multicolumn{2}{|c|}{$\begin{array}{l}\text { Proportion } \\
\text { Correctily } \\
\text { Identifying } \\
\text { Item ad } \\
\text { Meeded which } \\
\text { Hac } 5 \text { year } \\
\text { Payback }\end{array}$} & $\begin{array}{l}\text { Proportion of } \\
\text { Those tho } \\
\text { Identify } \\
\text { Iten at } \\
\text { Needed for } \\
\text { which Payback } \\
\text { is Greater } \\
\text { Then } 10 \text { years }\end{array}$ & $\begin{array}{l}\text { Proportion of } \\
\text { Entire Bample } \\
\text { Who identify } \\
\text { ltem as } \\
\text { Heeded then } \\
\text { Payback Is } \\
\text { Greater } \\
\text { Then } 10 \text { year. }\end{array}$ & $\begin{array}{l}\text { Proportion } \\
\text { correctly } \\
\text { IdentifyIng } \\
\text { Item ae } \\
\text { Heeded which } \\
\text { Had 5 year } \\
\text { Payback } \\
\end{array}$ & $\begin{array}{l}\text { Proportion of } \\
\text { Thoee Who } \\
\text { Identify } \\
\text { Item ae } \\
\text { Needed for } \\
\text { which Paybeck } \\
\text { is Greater } \\
\text { Than } 10 \text { yeardb }\end{array}$ & $\begin{array}{l}\text { Proportion of } \\
\text { Entire Sample } \\
\text { Who Identify } \\
\text { I tee a } \\
\text { Heeded When } \\
\text { Payback io } \\
\text { Greater } \\
\text { Than } 10 \text { yeara }\end{array}$ \\
\hline $\begin{array}{l}\text { Inaulation } \\
\text { (attic, wall or floor) } \\
\text { gtorb windoue }\end{array}$ & & $\begin{array}{l}49 x \\
\text { HA }\end{array}$ & $\begin{array}{l}17 x \\
81 x\end{array}$ & $\begin{array}{l}8 x \\
34 x\end{array}$ & $\begin{array}{l}372 \\
\mathrm{MA}\end{array}$ & $\begin{array}{l}17 x \\
70 x\end{array}$ & $\begin{array}{r}9 x \\
27 x\end{array}$ \\
\hline storn doors" & & MA & $100 x$ & $21 x$ & Ma & $100 x$ & $22 x$ \\
\hline Caulking/weatherstripping & & $25 x$ & $50 x$ & 132 & $25 x$ & $27 x$ & $6 x$ \\
\hline Hot water heater/pipe inaulat & tion & $2 \pi$ & $\mathbf{0 x}$ & $\mathbf{0 x}$ & $4 x$ & $60 x$ & $7 x$ \\
\hline
\end{tabular}

- - For unite for which the audit found that inetallatin or improvenent of the epeciffc weatherization feature would offer a five year or leas payback (contractor inatalled basis), this is the proportion of houaeholde wio identified the item as needed.

b - This column shows the proportion of houselrolds who identified this ites as one of the three most

important improvemente yet needed but for which the audit finds that contractor inatalled payback period would be wore than ten years. Referred to in text a error type $B$.

c - Thie column shows the proportion of entire audited ample who cite the itea as needed but for which contractor inatalled payback io ten years or greater.

d- Row shows respectively the proportion of those who say no improvemente are needed for wilch no item with five year payback is avallable; the proportion of those who ay no improvement is needed and for which all Improvements would require 10 years or greater payback; and the proportion of entire ample uho ay no improvements are needed and for which all improvements require ten year or greater payback.

e - Audits in both citiea found no households with contractor initalled windowo or doora that would provide a payback in five years or less.

f - First column figures show proportion of all households who identify correctly as needed one or more items that have a 5 year or less payback.

g - Cell proportion is $100 x$ based on one household who said clock thermontat was needed but for which contractor insialled payback would exceed 10 yeara. 
attractive potential of improved insulation of attic, walls, or floors i.e. made the least type A error. Roughly half the households for whom insulation offered an attractive payback "correctly" identified it.

While many households (25\%) said nothing more was needed, in D.C. none of these households were in the dwelling units for which the audit found no 5 year payback options. In Denver, only one-third of households without 5 year paybacks "correctly" said nothing more was needed. About one quarter of households with attractive (5 year) paybacks from caulking/weatherstripping identified that needed improvement in both sites. There was extremely low correct identification of water heater insulation and clock themostats. Overall, only 29 percent of households in D.C. and 30 percent in Denver could identify as needed one or more items suggested by the audit.

Colum two for each site in Table IV-3 shows the incidence for each item of error type B. The most frequent errors are apparent for storm windows and doors. Eighty are percent of households in D.C. and 70 percent of households in Denver who identified storm windows would not receive a payback from this option in less than 10 years. Over 20 percent made the equivalent "error" for storm doors. Those households who suggested caulking/weatherstripping had relatively high error rates as well ( 50 percent and 27 percent respectively). In Denver, of even the few households who said that water heater insualtion was needed, 60 percent would find that the payback was not attractive.

While the figures in colum one and two indicate errors for households identifying a particular item, column three offers a picture 
of the distribution of the greatest source of error across the entire sample. If households were to act on the improvements they identified, their figures would represent the proportion of households making the least attractive improvements.

The greatest misdirection of conservation effort would be for storm windows. Thirty-four percent of the D.C. sample and twenty seven percent of the Denver sample believe that storm windows are appropriate when their payback exceeds 10 years. 12 storm doors are the next most frequent mention of the less attractive improvement. The proportion selecting storm windows and doors equal to or exceed the proportion of households who would "ertoneously" make "no improvements." Investment in caulking/weatherstripping or water heater/pipe insulation would be inappropriately be undertaken by only a relatively small proportion of households.

\section{Summary Assessment of Household Conservation Rnowledge}

This section has been devoted to identifying various aspects of household knowledge concerning the most economically attractive options for energy saving imporements to their home. While these comparisons were relative (depending in part as our choice of 5 year and 10 year payback threshholds), it appear that there is a low knowledge within the samples about the potential for improvement overall and about the most appropriate sources of savings. Despite the apparent tendency for our

12. Ten year payback may still be attractive to a household and the investment may be appropriate. The ten-year payback threshhold is used only as a benchmark for analysis. Our figures should be used to identify relative ranking of appropriate investments rather than as accurate percentages of households for whom each investment is appropriate. 
audited subsamples to be households more attentive to the potential for energy savings and to be planning conservation invetments, about one quarter fail to identify any improvements (most have one or more) and except for insulation, tend to identify the "wrong" or less attractive item. While the most frequently cited rationale for utility audits is their stimulative effects-getting households to invest in some energy saving improvement-it appears that they also offer a potential to redirect household investment choices both away from less attractive items and toward more cost-effective (more frequently, lower cost) energy saving options.

From this perspective and because audits are a limited resource it may be important to direct audits toward those households least knowledgeable about conservation options. Identifying such households may not easy, however.

As a preliminary assessment of the distribution of accurate knowledge on conservation options, we have examined the relationship of several measures of conservation knowledge with selected household and dwelling unit characteristics. Table IV-4 shows these relationships. For subgroups, the table reports the proportion of households correctly identifying any item with a five year or less payback, the mean number of "correctly identified ( 5 year payback) items and the mean proportion of "correctly" identified items out of all items with 5 year paybacks. These measures capture different aspects of the extent of household knowledge but, upon examination, reveal similar patterns. Perusal of Table IV -4 indicates some interesting results. First, household income is positively but weakly related to the measures of 
TABLE IV-4

CILARACTERISTICS OF HOUSEIOLDS WITH KNOWLEDGE OF NEEDED MEATHERIZATION IHPROVEHENTS

\begin{tabular}{|c|c|c|c|c|c|c|}
\hline \multirow[b]{2}{*}{$\begin{array}{c}\text { Demographic, Conservation } \\
\text { Activity, and Attitudinal } \\
\text { Characteristics of } \\
\text { Householde }\end{array}$} & \multicolumn{3}{|c|}{ D.C. } & \multicolumn{3}{|c|}{ Denver } \\
\hline & $\begin{array}{l}\text { Proportlon } \\
\text { Correctly } \\
\text { Ident if fying } \\
\text { Any I tea } \\
\text { with } 5 \text { Year } \\
\text { Payback } \\
\end{array}$ & $\begin{array}{l}\text { Mean } \\
\text { Musber of } \\
\text { Correctily } \\
\text { Identified } \\
\text { Iteas vith } \\
5 \text { Year } \\
\text { Payback } \\
\end{array}$ & $\begin{array}{l}\text { Hean } \\
\text { Proportion } \\
\text { of } \\
\text { Correctly } \\
\text { Identified } \\
\text { Itens Out } \\
\text { of All Iteas } \\
\text { with S Year } \\
\text { Payback } \\
\end{array}$ & $\begin{array}{l}\text { Proportion } \\
\text { Correctly } \\
\text { Identifying } \\
\text { Any Item } \\
\text { with } 5 \text { Year } \\
\text { Payback } \\
\end{array}$ & $\begin{array}{l}\text { Mean } \\
\text { Muaber of } \\
\text { Correctly } \\
\text { Identified } \\
\text { Items with } \\
5 \text { Year } \\
\text { Payback } \\
\end{array}$ & $\begin{array}{l}\text { Hean } \\
\text { Proportion } \\
\text { of } \\
\text { Correctly } \\
\text { Identified } \\
\text { Items Out } \\
\text { of All Items } \\
\text { with's Year } \\
\text { Payback } \\
\end{array}$ \\
\hline \multicolumn{7}{|l|}{ Demographic Glaracteriotica } \\
\hline $\begin{array}{r}\text { Lescome Than } \$ 15,000 \\
\text { Greater Than } \$ 15,000\end{array}$ & 212 & .21 & $\begin{array}{l}.10 \\
.19\end{array}$ & 232 & .30 & $\begin{array}{l}.10 \\
.11\end{array}$ \\
\hline $\begin{array}{l}\text { Education: Up to } 8 \text { years } \\
\text { Some high echool or more }\end{array}$ & $\begin{array}{l}182 \\
312\end{array}$ & .18 & $\begin{array}{l}.01 * \\
.24\end{array}$ & $\begin{array}{l}238 \\
278\end{array}$ & .33 & $\begin{array}{l}.13 \\
.15\end{array}$ \\
\hline $\begin{array}{l}\text { Elderly Only in Householda } \\
\text { Some Hon-Elderly }\end{array}$ & $\begin{array}{l}142 \\
322\end{array}$ & .14 & $\begin{array}{l}.07^{\star} \\
.19\end{array}$ & $\begin{array}{l}178 \\
262\end{array}$ & $\begin{array}{l}.41 \\
.32\end{array}$ & $\begin{array}{l}.14 \\
.15\end{array}$ \\
\hline \multicolumn{7}{|l|}{ Congervation Characteristica } \\
\hline $\begin{array}{l}\text { Well Weatherized Unitc } \\
\text { Poorly Weatherized }\end{array}$ & $\begin{array}{l}16 \pi \\
112 x\end{array}$ & $\begin{array}{l}.18^{\star \star} \\
.47^{\star}\end{array}$ & $\begin{array}{l}.08^{4 *} \\
.29\end{array}$ & $\begin{array}{l}252 \\
272\end{array}$ & $\begin{array}{l}.39 \\
.27\end{array}$ & $\begin{array}{l}.16 \\
.11\end{array}$ \\
\hline
\end{tabular}

* Significantly different at .l level.

« Signficiantly different at.05 Ievel.

a "Elderly only" householda have one or more adults over age 60 and no other persons.

b - Scale is based on number of major efficiency improvementa made since moving into unit (includes attic and wall insulation, storm vindows and doors).

c - Scale based on presence of four major efficiency improvements (as in 'b' above) as identifed by respondent. 
conservation knowledge. Formal education of the household member shows a expected relationship with better educated having higher scores on each measure in both sites (only one relationship is significant at .1 or better, however). Elderly households are markedly less likely to score high in D.C. (one significant relationship) but this pattern is not true in Denver.

The relationship of conservation knowledge to two key conservation characteristics of households shows several non-obvious and significant results. Households who have been most active in the past in installing major features have lower scores on all conservation knowledge measures. Even if these households live in units with better thermal status (as captured in measure three), the active households typically identify a lower proportion of the (fewer) remaining attractive items. A similar pattern exists for households differentiated by the weatherization status of their units in D.C. D.C. households in poorly weatherized units, in fact, are significantly more likely to correctly identify potential sources of savings. In Denver, households in we11weatherized units do not significantly indicate greater conservation knowledge.

In interpreting these findings, we can suggest two possible factors. Those who have been active or who live in units with major conseration features in place are "guessing" at what needs to be done. They may fail to identify improvement to existing thermal features and may "misspecify" other items which do not offer returns as attractive as improvement to existing features. Alternatively, these households still interested in further conservation may be willing to accept (presumably) 
lower paybacks (not attractive by 10 year criteria) as they "fine tune" the efficiency of their units. ${ }^{13}$

These findings offer two extended implication. In section II, we found that education was among the few factors related to audit interest. In this section we find that based on several rather exacting tests of conservation knowledge, the better educated or more knowledgedable. This supports contention that audits may be requested by those less likely to benefit from them.

The second implication, however, is that audits might still be directed to active households and those well weatherized. Audits could contribute to more rational decisions on further investments by these households. They might in fact deter some investiment. Thus, they could contribute to overall "efficiency" in the purchase of energy services but dampen reductions in energy consumption. These issues pertaining to the effect of the audit in conservation improvements will be addressed in the subsequent report.

13. This would be consistent with results of section III where we find that detailed payback calculations are not a dominant feature of conservation decision making. 


\section{Appendix}

\section{Material Related to Energy Audits Conducted}

by Three Utility Companies For This Study 
This Appendix provides supplemental information on the energy audits which were used in this study. The audits were conducted by utility companies at our request under the RCS format. Included in the latter half of the appendix are samples of the results forms showing the cost, annual savings, payback calculations and related information for conservation items which was provided in written form to audited households.1

The three utilities involved (two in D.C. and one in Denver) each used its own model for calculating the proposed energy savings. Essential information provided to the household was similar for each utility in most respects, with the exception of the number of items evaluated.2 Presentational format differed, however, as is evident in the sample results forms provided.

The most important difference in presentation was between D.C. utility \#2 and the other two companies. Utility \#2 sent audit results to the home in booklet form two to three weeks after the audit was conducted. The other two utilities used a telephonic time-sharing computor hook-up by which audit input data was transmitted to a central computor facility. Within five to fifteen minutes, the data on potential payback for installation of conservation items was available. Consequently, the audit recommendations could be discussed with the household member by the auditor and the results left at the

1. For discussion of the procedures by which audit was conducted, see text of this paper and sections of background paper The Residential Conservation Gap Study: Purpose, Research Design and Data Description, Paper \$3030-01, October 1981 .

2. The Denver audit provides extensive evaluation of several solar options which were not covered in the D.C. audits conducted for the study. 
site upon completion of the visit. It is not known whether these different approaches might affect the subsequent effectiveness of the audit in stimulating conservation investment.

Because the audit results are important to several aspects of this study, we attempted to to assessed whether there was any basic incompatability between audit results from the three utilties. Site differences between Denver and D.C., of course, were to be expected because of housing construction practices and the typical conservation status of the housing stock which varies by region and climate. Unfortunately, we are not able to perform extensive multi-variate analysis which would permit comparsion among utilties of houses similar on all factors relevant to the audit. However, several simple comparisons do support our confidence in audit comparability. Information in Table A-l provides two sumbary comparisons of audit results for six items evaluated by all three utilities. The first comparison is in terms of the proportion of audited units with non-zero savings on each conservation item; the secnd comparison is of average savings for all units that had some savings potential identified (this is done without respect to conservation costs or payback).

Columns 1 and 7 show the first measure for both DC utilities combined and the Denver utility. Caulking/weatherstripping savings are evident for $90 \%$ percent of households in both sites. Savings for attic insulation, wall insulation and floor ingulation is evident in a majority of households in both D.C. and Denver.

The proportion of households with floor insulation, storm doors and water-heater insulation savings is quite a bit lower in Denver than in 
TABLE A-1

CORPARISON OP ETALDATION OR MAJOR FEATURES NWONG TRRES UTIIITIES PROVIDING AUDITS

\begin{tabular}{|c|c|c|c|c|c|c|c|c|}
\hline \multirow{3}{*}{$\begin{array}{l}\text { Conservation } \\
\text { I Eeme Evaluated } \\
\text { By AlI Utilities }\end{array}$} & \multicolumn{6}{|c|}{ D.C. Ocilifies } & \multicolumn{2}{|c|}{ Denver } \\
\hline & \multicolumn{2}{|c|}{ Combined D.C. } & \multirow{2}{*}{$\begin{array}{l}\frac{\text { Deiliey }}{\text { Average }} \\
\text { Annual } \\
\text { Savings }\end{array}$} & \multirow{2}{*}{$\begin{array}{l}\text { Average } \\
\text { Ammal } \\
\text { Savings }\end{array}$} & \multicolumn{2}{|l|}{ Veilicy \$2 } & \multirow[b]{2}{*}{$\begin{array}{l}\text { 7 With } \\
\text { Nanzero } \\
\text { Savings }\end{array}$} & \multirow[b]{2}{*}{$\begin{array}{l}\text { Average } \\
\text { Anmual } \\
\text { Savinge }\end{array}$} \\
\hline & $\begin{array}{l}\text { Wieb } \\
\text { Non-zaro } \\
\text { Savings }\end{array}$ & $\begin{array}{l}\text { Average } \\
\text { Aanual } \\
\text { Savinge }\end{array}$ & & & $\begin{array}{l}\text { Gas-Heaced } \\
\text { gooses } \\
\text { Savings }\end{array}$ & $\begin{array}{l}\text { Oil-Hiented } \\
\text { gowes } \\
\text { Savings }\end{array}$ & & \\
\hline $\begin{array}{l}\text { Caulking/ } \\
\text { Wencherstripping b }\end{array}$ & 902 & $\$ 26$ & $\$ 22$ & $\$ 29$ & $\$ 25$ & $\$ 39$ & 918 & $\$ 37$ \\
\hline Atric Iasulation & $75 \%$ & $\$ 145$ & $\$ 89$ & $\$ 175$ & $\$ 147$ & $\$ 226$ & 817 & $\$ \$ 3$ \\
\hline Wall Inaulation & $35 \pi$ & $\$ 165$ & $\$ 107$ & $\$ 204$ & $\$ 163$ & $\$ 258$ & 778 & $\$ 83$ \\
\hline Floor Insulation & 597 & $\$ 41$ & $\$ 19$ & $\$ 32$ & $\$ 46$ & $\$ 64$ & 397 & $\$ 30$ \\
\hline Srorm window & 787 & $\$ 69$ & $\$ 59$ & $\$ 75$ & $\$ 68$ & $\$ 96$ & 652 & $\$ 39$ \\
\hline Storm Doors & 498 & $\$ 15$ & $\$ 10$ & $\$ 18$ & $\$ 18$ & $\$ 21$ & 178 & $\$ 2$ \\
\hline Hater Heater Wrap & 907 & $\$ 16$ & $\$ 17$ & $\$ 14$ & $\$ 14$ & $\$ 14$ & 427 & $\$ \$$ \\
\hline
\end{tabular}

a - Three different utility companies provided audits for the study. Utility 1 in D.C. and the Denver utility did audit only for gas-heated howas for which utiliey records provided consumption data. D.C. utilicy $\$ 2$ audies were divided roughly becween rwo-thirda gas-tented homas and one-chird oil heaced homes. Actual consumption data vas available for about hall of anch group for this utility. An estimated consumption figure was provided for the other half of homes audited by the utilicy. All dollar figures are the utilicy's estimated anaual savings which would resule froe installing or adding to the masure whecher or not if offered a high pay back. Averages as presenced are means over all households for which non-zero savings were idearified.

b Caulking and weatherstripping weze evaluated geparately by D.C. usility 1 and the Denver utilicy. D.C. usility $\$ 2$ provided only a combined escimete of caulking and weatherscripping gavings. For comparability across all three utilities, we sumand the savings for boch ictme when ic originally appeared geparacely. 
D.C. The first two items probably reflect real differences in housing characteristics (all D.C. households have basements, many Denver homes are on slabs. The ( $90 \%$ versus $42 \%$ ) difference in proportions of water heater savings way reflect differences in the audit assumptions about water heater insulation and the feasibility of insulating water heaters located in heated space. (Utilities tend to estimate savings from water-heater insulation as a flat dollar amount which does not reflect household usage-probably because water heater insulation is both a low cost and a source of low savings.

In the comparison, more striking differences between sites are found in the average annual savings estimates (shown only on the bases of units with non-zero savings-colums 2 and 8 ). The D.C. audits estimate substantially larger savings for attic insulation; for example savings average $\$ 145$ in D.C. (column 2) compared to only $\$ 53$ in Denver (column 8).

These differences may reflect average differences in existing levels of insulation as well as fuel price, climate, and consumption patterns. Attic insulation is more common in Denver. (In our baseline survey, 77 percent of households report some attic insulation versus 56 percent in D.C.). Average fuel/electricity prices are also lower in Denver. Winters are colder and sumers less hot. Since attic insulation savings also came from reduced summer cooling costs in the audit models, (if air conditioning is used) climate could have a large effect on savings potential.

Other factors may be important in addition to these site differences, however. We have noted that one of the D.C. utilities (非) 
has markedly higher savings estimates (compare columns 3 and 4.) While differences in audit procedures between the two D.C. utilities might be responsible, a large portion of that difference can be explained by the the fuel type of the households audited. D.C. utility 1 audited only gas heated homes (as did the Denver utility) while abot $40 \%$ of the audits of D.C. utility $\$ 2$ were in oil-heated homes. The average savings estimates are much more comparable among the gas heated homes (compare columns 3 and 5) although still somewhat higher by utility 2 . The higher costs of heating with fuel oil coupled with the liklihood that oil-heated homes are larger, older and more poorly insulated in D.C. (many restoration and repairs to older homes in this area in D.C. include conversion to gas heat) are possible causes of the larger average savings for these homes which were estimated by utility \#2.

That remaining differences in average savings wight reflect differences in the utility models cannot be ruled out for certain. However, based on this comparison of typical savings variation by type of heating, and other possible differences in the characteristics of these homes and climate differences, we believe the evidence is in favor of at least rough comparability of the evaluation outputs produced by the three utilities' audit models. 


\section{Sample}

\section{Audit Results Forms}

\section{from}

\section{D.C. Utility 1}

These forms were filled-in by the auditor and left with the household member. Results were explained by the auditor and questions about the recommendations were answered at the completion of the audit. 


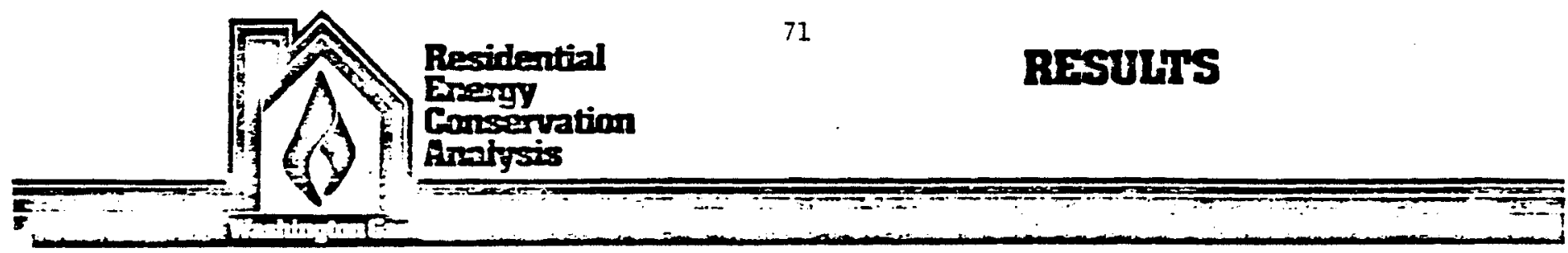

Prepared for

Phone

CUSTOMER ACCOUNT NO.

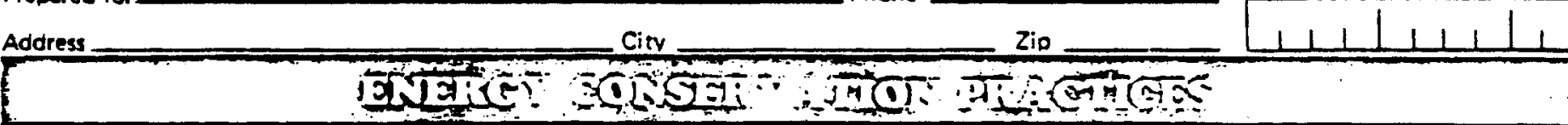

In Item is checked if applicable to your home. It is recommended that these practices be implemented before installation of any conservation or renewable resource measures.

1) Clean and perform combustion efficiency adjustment on your gas or oil furnace regularly, at least once per heating season.

2) Replace the air filters on your central heating system regularly.

3) Lower the bonnet or plenum thermostat temperature to $80^{\circ} \mathrm{F}$ on your gas or oil forced air furnace.

4) Tum the pilot light off on your gas furnace during the summer months.

5) Lower the thermostat control setting for the furnace in the heating season to a maximum of $55^{\circ} \mathrm{F}$ during sleeping hours.

6) Limit the thermostat control setting for the furnace in the heating season to a maximum of $68^{\circ} \mathrm{F}$ during waking hours.

7) Limit the thermostat control setting for the air conditioner in the cooling season to a minimum of $78^{\circ} \mathrm{F}$.

8) Restrict the flow of water in your shower heads or faucets to a maximum of three gallons per minute using either flow restrictors or replacing existing shower heads and faucets with those having built-in provisions for water flow re duction.

9) Reduce the water heater thermostat setting to $120^{\circ} \mathrm{F}$ and reduce use of heated water for clothes washing. (Caution-some dishwashers require $140^{\circ} \mathrm{F}$ water.)
10) Lower the thermostat setting to $55^{\circ} \mathrm{F}$ when your home is empty for four hours or longer in the heating season.

11) Turn off the air conditioner in the cooling season when no one is at home.

12) Turn the water heater off when your home is vacant for two days or longer.

13) Install scrap insulation or other pliable fireproof material in gaps around pipes, ducts, fans, or other items which enter your attic or basement from a heated space.

14) Install fireproof material to plug any holes around any damper in your fireplace.

15) Add insulation to your attic or basement door.

16) Seal leaks in your heating or cooling ducts.

17) Tighten or plug leaking joints in your hot water or steam pipes.

18) Replace the washers in your leaking water faucets.

19) Use your shades and drapes to:

11 block the sunlight from entering your home in the cooling season

2) allow the sunlight to enter your home dur. ing the heating season, and

3) cover your windows tightly at night during the heating season.

The Energy Conservation Practices as checked above have been explained to me.

Customian

sienature
Energy

Anaverse Date 


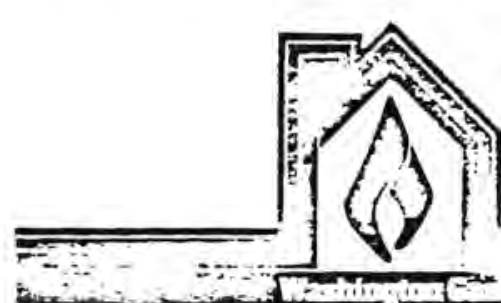

Residential

Enearyy

Conservation

Ansitysis

\section{RESULTS}

Address City Zip

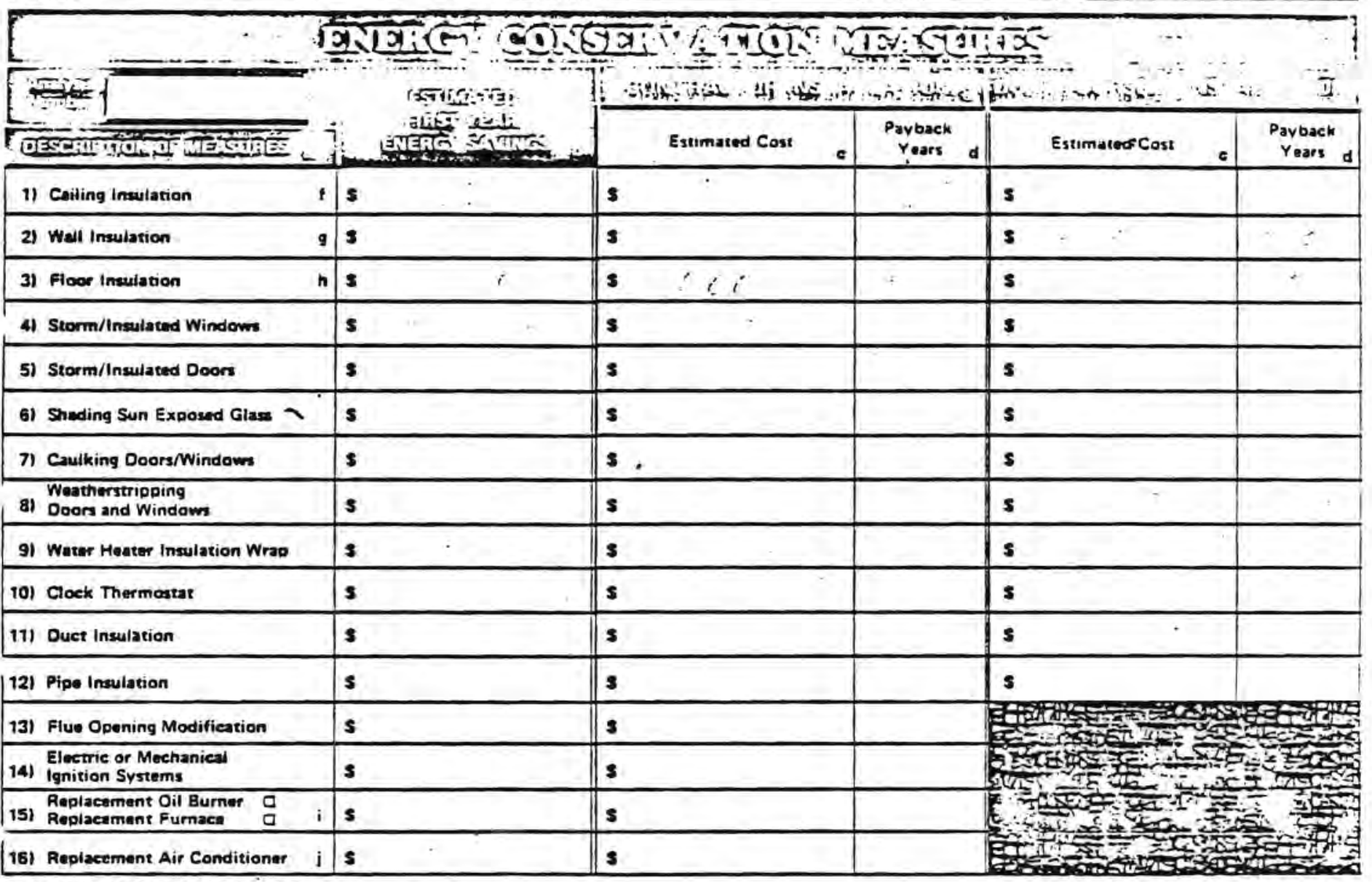

Soo reverse side for notes a through $k$.

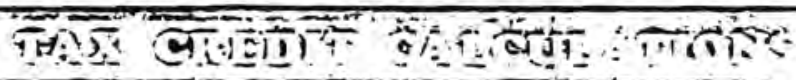

The federai government provides tax incentives to encourage the installation of energy conserva. tion products. A tax credit applies to the cost of items installed after April 19, 1977 and before January 1, 1986. Details can be found in IRS publication 903, or by calling your local 1 RS office.

If a state credit is shown in the sample caiculation, you may determine more specific information by contacting your local tax office.

The sample calculation provided here applies to item(s) of the anaiysis.

\begin{tabular}{|c|c|}
\hline Coss of System & s \\
\hline Foderad Tax Credit & $s=$ \\
\hline $\begin{array}{l}\text { State Tax Credit } \\
\text { Cost of System with } \\
\text { tax eradit deducted }\end{array}$ & \\
\hline
\end{tabular}

The resuls of this Residential Energy Consenation Analysis and the notes on the back of this form have been explained to me and I have been offerod assistance in arranging installation-and finencing of the Energy Conservation Measures.

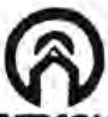

Brion Customer Enercom - A service of Wanington Gas Liont $\mathrm{Ca}$
Energy

Anaiyst

WMITE - HOMIOWMEN COPR - YELLOW AMMK - WASHIMGTON OAS COMES 
Sample

Audit Results Forms

from

D.C. Utility \#2

The following are selected pages from the report, summarizing audit recommendations for the dwelling unit. The report was sent to the household one to three weeks after the utility's on-site inspection. Low-cost tips checked in the booklet were discussed at the time of the audit. One distinctive feature of this audit report is inclusion of a recommended list of insulation contractors and of local financial institutions which make loans for conservation improvements. 


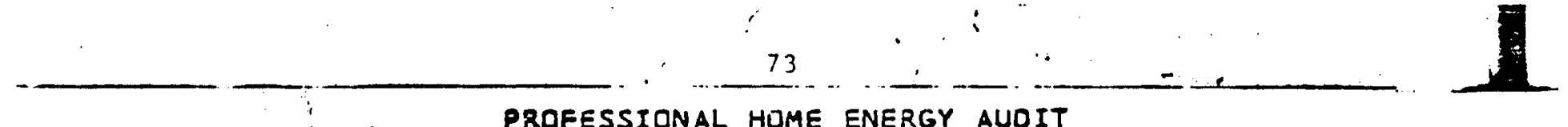

PROFESSIONAL HUME ENERGY AUDIT

SECTION II A

INSULATION RECOMMENDATIONS

A COMPARISON WAS MAOE BETWEEN THE EXISTING INSULATING QUALITIES OF YOUR HOME AND THOSE RECOMMENDED GESTED TO MAKE YOUR HOME MORE ENERGY EFFICIENT ANO TO INCREASE ITS LEVEL DF COMFORT.

\begin{tabular}{|c|c|c|c|}
\hline SURFACE & $\begin{array}{l}\text { AREA } \\
\text { SQ. FT. }\end{array}$ & $\begin{array}{l}\text { PRESENT } \\
\text { R VALUE }\end{array}$ & RECOMMENDATIONS \\
\hline DOORS & & & $\begin{array}{l}\text { THE DOORS WITHOUT A STORM DOOR, EXCEPT } \\
\text { FOR SLIDING GLASS DOURS, SHOULD BEPRO- } \\
\text { TECTED WITH A STORM DOOR. }\end{array}$ \\
\hline HINDOWS & & & $\begin{array}{l}\text { THE SINGLE GLASS WINDOWS SHOULD } 8 E \text { PRO- } \\
\text { VIDED WITH STORM WINDOWS }\end{array}$ \\
\hline BALLS & 1480 & 0.0 & $\begin{array}{l}\text { THE THERMAL INSULATION IN THE WOOD FRAME } \\
\text { WALLS SHOULO BE INCREASED TO AN R VALUE } \\
\text { OF } 11.0\end{array}$ \\
\hline \multirow[t]{2}{*}{ CEILIN } & 135. & 0.0 & $\begin{array}{l}\text { THE THERMAL INSULATION IN THE CEILING } \\
\text { BELOW THE VENTILATED ATTIC SHOULD BE IN- } \\
\text { CREASED TO AN R VALUE OF } 30.0\end{array}$ \\
\hline & 663. & 7.0 & $\begin{array}{l}\text { THE THERMAL INSULATION IN THE CEILING } \\
\text { BELOW THE VENTILATED ATTIC SHOULD BE IN- } \\
\text { CREASED TO AN R VALUE OF } 30.0\end{array}$ \\
\hline $\begin{array}{l}\text { HEATHERSTR } \\
\text { CAULKING }\end{array}$ & IPPING AND & & $\begin{array}{l}\text { THE OVERALL CONDITION OF THE CAULKING } \\
\text { AND WEATHERSTRIPPING AROUND DOORS AND } \\
\text { WINDOWS SHOULD BE UPGRADED TO ACHIEVE } \\
\text { COST SAVINGS AND COMFORT. }\end{array}$ \\
\hline $\begin{array}{l}\text { WATER HEAT } \\
\text { TANK INSUL }\end{array}$ & $\begin{array}{l}\text { ER STORAGE } \\
\text { AT ION }\end{array}$ & & $\begin{array}{l}\text { ADDITIONAL BLANKET INSULATION SHOULD } 8 E \\
\text { AOOED TO YOUR GAS WATER HEATER STORAGE } \\
\text { TANK. IT IS AVAILABLE IN KIT FORM FROM } \\
\text { LOCAL OEALERS ANO HARDWARE STORES. }\end{array}$ \\
\hline
\end{tabular}




$$
\begin{aligned}
& \text { '74 } \\
& \text { PROFESSIONAL HOME ENERGY AUDIT } \\
& \text { SECTION II-B } \\
& \text { INSULATION RECOMMENOATIONS }
\end{aligned}
$$

IN AODITION TO THE RECOMMENDATIONS MADE IN SECTION II-A, THE REMAINING AREAS OF YOUR HOME WERE EVALUATED WITH RESPECT TO PEPCD STANDARDS.

THE FOLLOWING STRUCTURAL AREAS MEET OUR RECOMMENDED THERMAL INSULATION STANDARDS.

$$
\text { FloORS GVER CRAHL SPACE }
$$

THE FOLLOWING STRUCTURAL AREAS HERE CHECKEJ AND OID NOT MEET OUR RECOMMENDED THERMAL INSULATION STANDARDS. A SPECIFIC IMPROVEMENT RECOMMENDATIIN WAS NOT MAOE DECAUSE OF THE DEGREE OF DIFFICULTY ANO/OR EXPENSE USUALLY ENCOUNTERED IN MAKING THE IMPROVEMENT.

WALLS

CEILINGS

MASONRY, FURRED

FLAT ROOF 


PROFESSIONAL HOME ENERGY AUDIT
SECTION IV
INSULATION IMPRUVEMENT VALUE

THE RECUMMENDATIONS: ARE RANKED BELOW IN THE ORDER IN WHICH THEY SHDULD BE PERFORMED. FOR EACH ITEM, WE ESTIMATED THE FIRST-YEAR HEATING AND COOLING SAVINGS ANU THE COST TO SUY AND INSTALL. THEN HE ESTIMATED THE NUMGER DF YEARS NEEUED TO PAY BACK THE COST OF THE IMPROVEMENT. KEEP IN MIND THAT YOUR ENERGY COSTS WILL VARY DEPENDING ON THE WEATHER, ENERGY PRICES, ANU THE WAY YOU USE YOUR SYSTEMS, SO THE DOLLARS AND THE YEARS SHOWN MAY NOT BE EXACTLY WHAT YOU WILL EXPERIENCE. BUT BECAUSE THE CALCULATIONS WiRE MADE THE SAME WAY FOR EACH ITEM, THE RANKING SHOULD STAY THE SAME.

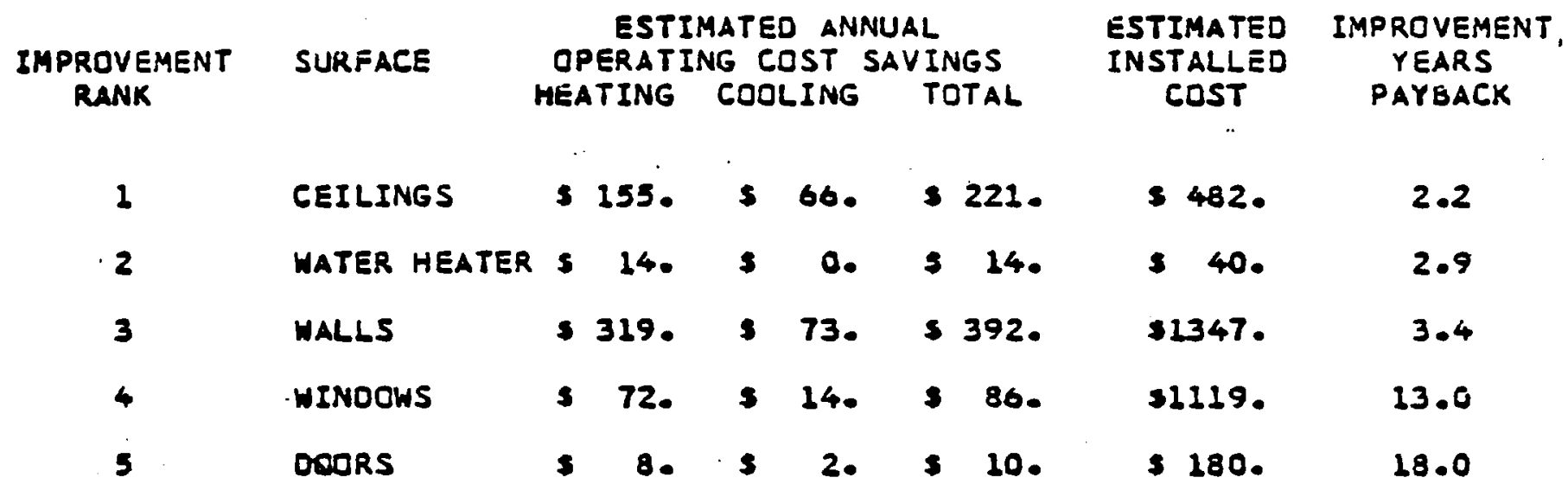

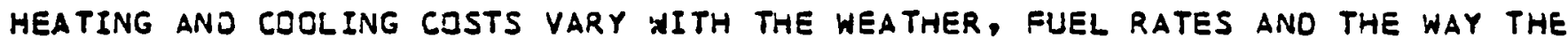
SYSTEMS ARE USED. THE ESTIMATED ANNUAL SAVINGS SHOWN ABOVE ARE BASED CN CALCULATIJINS WHICH PKOJECT THE ANNUAL HEATIIU COST TO SE ABOUT \$1640 ANO THE ANNUAL CUULING COSTS TO BE ABOUT $\$ 484$.

IF THE AVERAGE COSTS ACTUALLY EXPERIENCED OIFFER FROM THESE PROJECTIONS, THE ESTIMATED ANNUAL SAVINGS SHOWN FOR IMPROVING THE THERMAL INSULATION OF YOUR HOME MAY DE AOJUSTED PROPORTIUNALLY.

THE INSTALLED COST OF EACH IMPROVEMENT HAS BEEN ESTIMATED BASED ON AVERAGE LABOR RATES AND MATERIAL PRICES FOR A GOOD UUALITY PRODUCT. THE ACTUAL COST MAY VARY SIGNIFICANTLY FROM THE ESTIMATE UEPENDING ON WHO PERFORMS THE WORK, WHAT MATERIAL IS USED AND HOW DIFFICULT THE JOB MAY BE. THE COST OF SOME JOBS MAY BE SIGINIFICANTLY REDUCED IF YOU PERFORM THE WORK YOURSELF.

THE ESTIMATED SAVINGS FROM INSULATION FOR HEATING ANO COOLING COSTS HAVE BEEN CALCULATED BY ASSUMING THAT CAULKING AND WEATHERSTRIPPING AROUND OOORS AND WINDOWS WILL BE IMPROVED AS RECOMMENDEO IN SECTION II. IF THE WEATHERSTRIPPING ANO CAULKING ARE I:APROVED AND THE RECOMMENDED INSULATION IMPROVEMENTS ARE MADE AN ADOITIUNAL SAVINGS OF $\$ 1.00$ IN HEATING AND COOLING COSTS CUULD BE DBTAINED. 

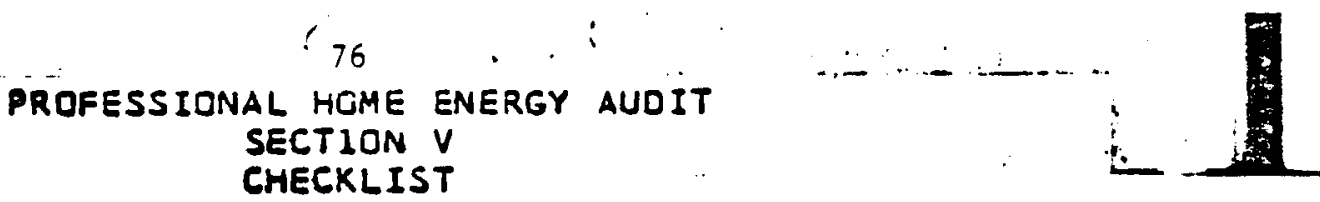

THE FOLLOWING STEPS SHOULD ALSO BE CONSIDERED TO REDUCE YOUR HOMES ENERGY REQUIREMENTS. THEY WILL ALSO MAKE IT A MORE COMFORTABLE PLACE TO LIVE.

1. AWNINGS INSTALLED ON WINOOWS AND DOORS FACING THE SUM REDUCE THE AMOUNT OF UNWANTED HEAT ENTERING YOUR HOUSE DURING THE CDOLING SEASON.

2. IMPROVE COMFORT AND LOWER AIR CONDITIONING COSTS BY INSTALLING SPECIAL HEAT REFLECTIVE MATERIAL ON SOUTH FACING WINUOWS ANO GLASS DOURS. THIS SPECIAL MATERIAL IS TYPICALLY A PLASTICAMETALLIC FILM INSTALLED ON THE INSIDE off THE hINDOW.

IT COSTS ABOUT \$1.5O PER SQUARE FOOT TO BUY.

3. A KITCHEN EXHAUST FAN SHOULD IDEALLY BE LOCATED DIRECTLY QVER THE RANGE AND VENTED TO THE OUTDOORS. IT CAN IMPROVE COMFORT IN SUMMER BY REMOVING UNHANTED HEAT ANO MOISTURE BUT SHOULD BE USED SPARINGLY IN WINTER.

4. AN EXHAUST FAN IN THE BATHROOM VENTED TO THE OUTOOORS CAN IMPROVE COMFORT BY REMOVING UNHANTED HEAT AND MOISTURE IN SUMMER. THE BEST LOCATION FOR THE FAN IS IN THE CEILING BUT NOT DIRICTLY IVER THE TUB OR SHOWER. USE IT SPARINGLY IN THE WINTER.

5. PRUPER ATTIC VENTILATIUN IS IMPORTANT IN REDUCING THE POSSIOILITY OF UNAANTEO MOISTURE BUILDUUP IN THE ATTIC OURING WINTER MUNTHS. PROPER ATTIC VENTILATION WILL ALSO KEEP THE HUUSE COOLER IN SUMMER BY REDUCING THE AMOUNT OF HEAT BUILD UP IN THE ATTIC.

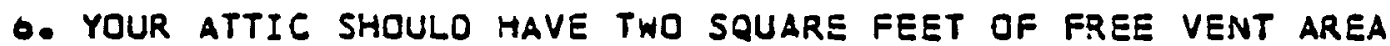
FOR EACH 300 SQUARE FEET OF ATTIC FLODR. THE VENTS SHOULD BE LOCATED AT UPPOSITE ENOS OF THE ATTIC. (FREE VENT AREA IS AREA UNDBSTRUCTED BY LOUVERS AND/OR SCREENING. IF A VENT COVERING IS USED, THE AREA OF TAE OPENING MUST BE

- INCREASED AS DESCRIBED IN OUR "DO-IT-YOURSELF INSULATION GUIUE.")

7. A POWER VENT FAN INSTALLED IN YOUR ATTIC ROOF OR GABLES CAN REDUCE THE HEAT GAIN OF YOUR HOME IN THE SUMMER. THIS WILL REDUCE THE AMOUNT OF HEAT THAT YOUR AIR CONOITIONER HAS TO REMOVE TO COOL YOUR HOME TO THE OESIRED TEMPERATURE. IT MAY ALSU ELIMINATE THE NEED FOR USING YOUR AIR CONDITIONING SYSTEM IN ALL BUT THE HOTTEST DAYS IN THE SUMMER. IT WILL NOT, HOWEVER, REMOVE UNWANTED MOISTURE FROM YOUR HOME IN THE SUMMER. WINTER. 


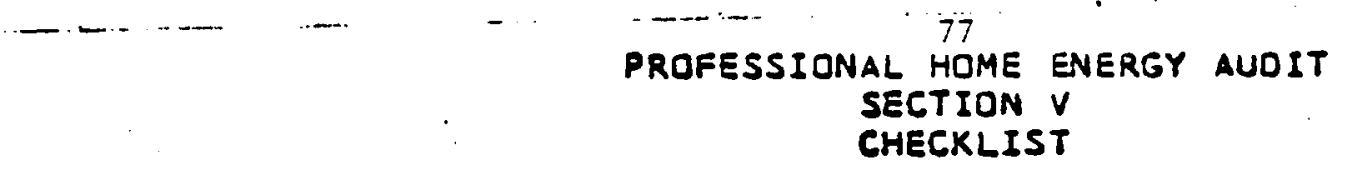

CHECKLIST

LOW COSTANO COST HAYS TO SAVE ENERGY

THE AMOUNT OF ENERGY USED IN YOUR HOME IS LARGELY DETERMINED BY THE WAY YOU USE ENEKGY CINSUMING EOUIPMENT AND BY YOUR HAOITS. THE FOLLOWING ENERGY SAVINGS TIPS GENERALLY COST LITTLE OR NOTHING AND CAN HELP YOU REDUCE ENERGY CONSUMP TIDIV.

HEATING SEASON

9. THE RECOMMENUED WINTER HEATING THERMOSTAT SETTING IS 68 DEGREES DURING PERIODS WHEN THE HOME IS OCCUPIED. EVERY DEGREE OVER OB DEGREES INCREASES THE HEATING ENERGY REQUIRED BY ABOUT 3 PERCENT.

10. IN ORDER TO MAINTAIN THIS SETTING OF 63 DEGREES IN ALL HEATEO AREAS OF THE HOUSE. THE OUCT OR AIR OISTRIBUTION PROBLEM THAT EXISTS SHOULO BE CORRECTED BY A HEATING AND AIR CONDITIONING CONTRACTOR.

11. IF YOU PLAN TO BE AHAY FROM HOME FOR A FEH DAYS OR LONGER, THE TEMPERATURE SETTING SHOULD BE REDUCED TO 55 DEGREES. TO PREVENT WATER PIPES FROM FREEZING AND BURSTING, IT SHOULD NOT BE TURNED OFF ENTIRELY.

COOLING SEASON

12. SET AIR CONUITIONING THERMOSTATS NO LOWER THAN 70 OEgREES. EVERY DEGREE UNOER 78 DEGREES USES ABOUT 5 PERCENT MORE ENERGY.

13. IN. ORDER TO MAINTAIN THE RECOMMENDED THERMOSTAT SETTING DF 78 OEGREES IN ALL AREAS OF THE HUME, THE DUCT OR AIR OISTRIBUTION PROBLEM SHOULD BE RESOLVED BY A HEATING AND AIR CONDDITIONING CONTRACTOR.

14. TURN OFF OR SET UP THE THERMOSTAT ON WINOOW AIR CONDITIONERS IN RODHS THAT WILL BE UNOCCUPIED FOR SEVERAL HOURS. CLOSE THE DOORS TO RUOMS LEFT. UNOCCUPIED.

15. WHEN STARTING THE AIR CONDITIONER, DO NOT SET THE THERMOSTAT LOWER THAN 78 OEGREES IN AN EFFORT TO COOL YOUR HOUSE FASTER. SUCH A PRACTICE IS INEFFECTIVE ANO WILL WASTE ENERGY IF OVERCOOLING OCEURS.

16. CLOSE DRAPES BLINDS AND CURTAINS ON WINDOWS FACING THE SUN TO REDUCE THE AMOUNT OF UNWANTED HEAT ENTERING YOUR HOUSE DURING THE COOLING SEASON. 
The structural characteristics of the home mave been used to calculate meat LOSS ANU HEAT GAIN DATA AS WELL AS ANNUAL ENERGY REQUIREMENTS AND. THE CORRESPONDING OPERATING COSTS. THE PRIMARY USE OF THIS REPORT IS TO PROVIUE THE HOMEOWNER WITH ADOITIONAL INFORMATION WITH RESPECT TU THE WAY ENERGY IS BEING USED FOR SPACE HEATINE ANO CUOLING.

HEAT LOSS ANO HEAT GAIN:

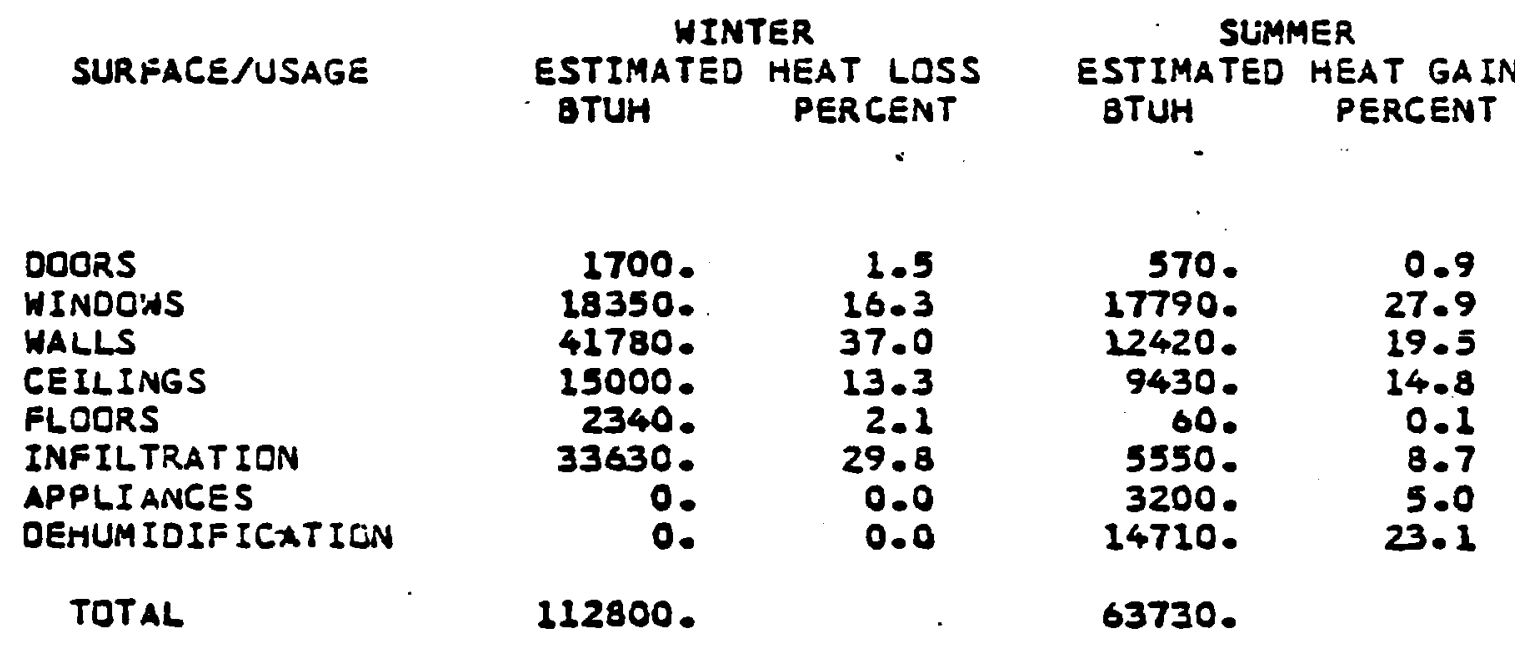

THE HEAT LOSS AND GAIN SHOWN AS INFILTRATION IS THE ENERGY REQUIRED TO HEAT AND COUL THE QUTSIUE AIR THAT LEAKS INTO YOUR HOME. THE APPLIANCE HEAT GAIN IS FOR THE OCCUPANTS AND HEAT PRODUCING EQUIPMENT IN THE HOME. THE OEHUMIOIFICATION HEAT GAIN IS FOR REMOVING WATER VAPOR FROM THE HOME IN SUMMER.

HEATING ANO COOLING ENERGY AND COSTS:

ELECTRICITY

FUEL

SPACE HEATING

ANMUAL ENERGY

ANNUAL COSTS

\section{AIR CONOITIONING}

ANNUAL ENERGY ANWUAL COSTS
749. KWHRS

341.

3846. THERMS $\$ 1600$.

THE ELECTRIC USAGE SHUHN FOR SPACE HEATING IS FOR THE ELECTRIC PUMPS OR FANS REQUIRED FOR THE FUEL FIRED SYSTEM TO OPERATE. 


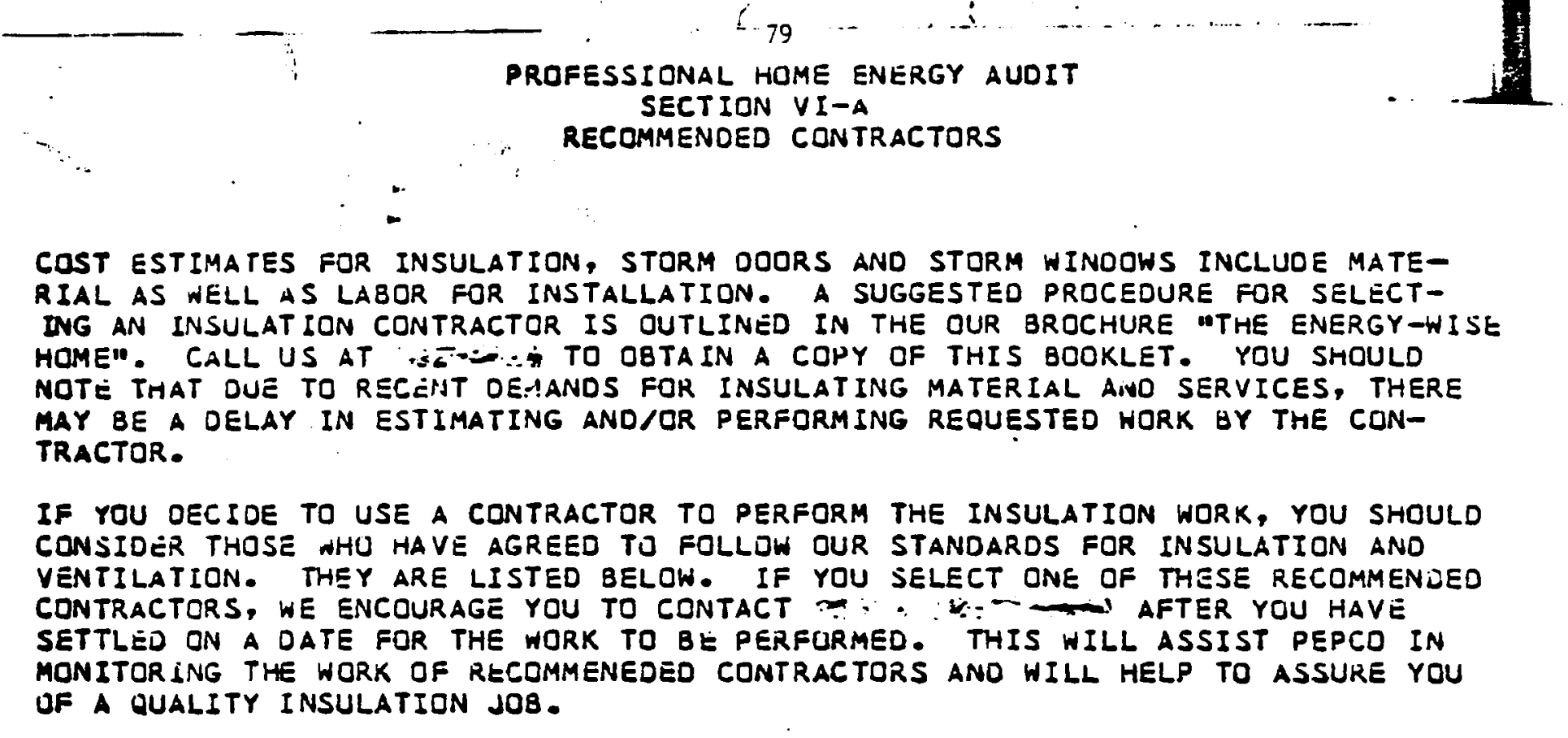

A. C. \& R. INSULATION CD., INC. 10310 SUUT HARD ORIVE

BELTSVILLE, MO. 20705

$937-4710$

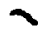

DAVENPORT INSULATION COMPANY 8420 TERMINAL ROAD

SPRINGFIELD, VA. 22150

550-9600

(AREA CDDE TO3)

INSULATORS OF MARYLAND, INC. 5951 HALPINE KOAD

ROCKVILLE, MARYLANO 20795

933-5566

(AREA CODE 301)
B 8 B INSULATION COMPANY

12324 WILXINS AVENUE

ROCKVILLE, MARYLAND 20852

$881-2700$

HODGES HOME INSULATING

6856 LEE HIGHWAY

ARLINGTON, VA. 22213

532-0184 


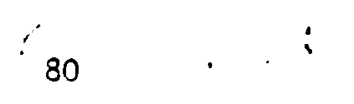

\section{PROFESSIONAL hOME ENERGY aUdit SECTION VI \& \\ LENOING INSTITUTIONS}

IF YOU WUULD LIKE TO CONSIDER A LOAN TO MAKE RECOMMENDED IMPROVEMENTS TO YOUR HOME, WE SUGGEST THAT YUU CONSULT YOUR OWN BANK REGARDING. THE AVAILABILITY OF FINANCING. IN THE EVENT THAT YOUR BANK DCES NOT OFFER SUCH TYPES OF LOANS, WE ARE FURNISHING A PARTIAL LISTING OF MAJOR FINANCIAL INSTUTIONS WHO HAVE INDICATED THEIR WILLINGNESS TO ACCEPT APPLICATIONS TO FINANCE HLME IMPROVEMENTS WHICH CONSERVE ENERGY.

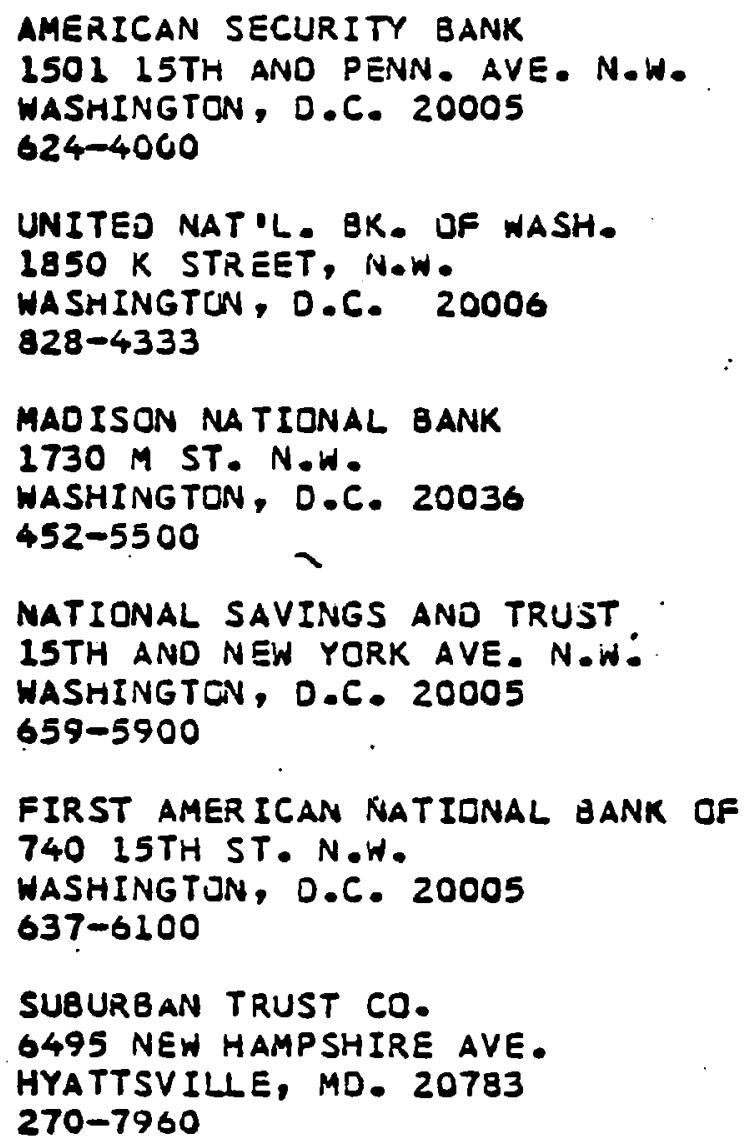

INDUSTRIAL NATIONAL BANK 4812 GEORGIA AVE. N.H. MASHINGTON, D.C. 20011 $722-2000$

MCLACHLEN NATIONAL BANK 11TH AND G ST. N.W. WASHINGTON, D.C. 20005 626-0100

MATIONAL BANK OF HASHINGTON 619 I4TH ST. N.W. HASHINGTON, D.C. 20005 $537-2000$

RIGGS NATIDNAL BANK 1503 PENN. AVE. N.H. HASHINGTON, D.C. 20005 $624-2000$

CITIZENS BANK AND TRUST OF MD. 6200 BALTIMORE BLVD. RIVERDALE, MD . 20840 $699-7235$

FIRST NATIONAL BANK OF MARYLAND 1 BANK STREET GAITHER SBURG, MD . 20760 926-0700 
Sample

Audit Results Summary

from

Denver Utility Company

These computor printed results were left with the household member at completion of the audit. Savings and payback data on the second page are keyed to page numbers in an accompanying printed booklet also provided at the time of the audit. The booklet pictured, described and explained the use of the conservation item and a simplified method of self-installation if appropriate. 


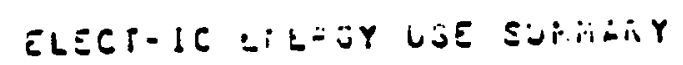

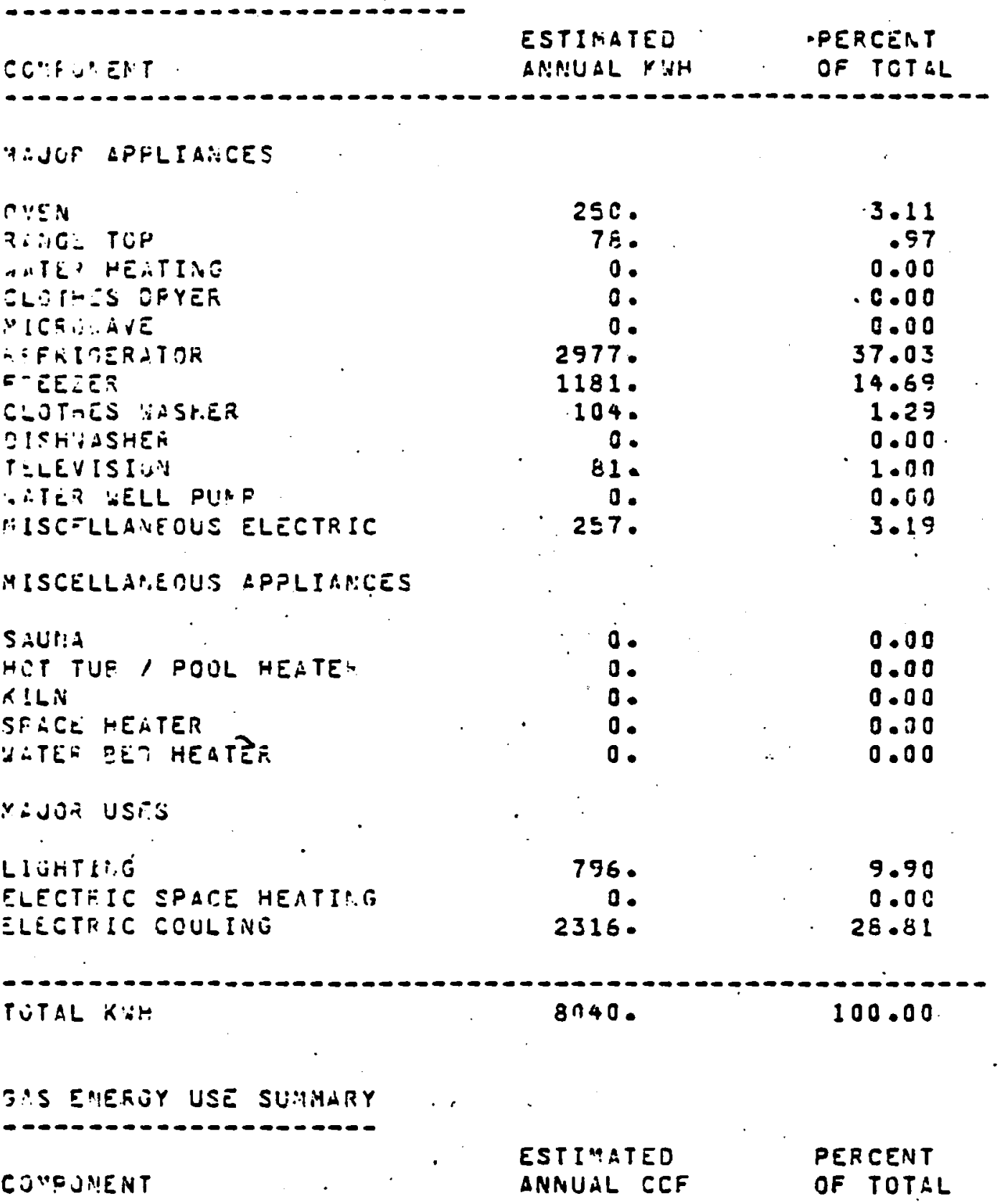

MANOS AFFLIANCES

$\begin{array}{lrr}\text { OVE: } & 0 . & 0.00 \\ \text { REPIGE TOP } & 0 . & 0.00 \\ \text { HATER HESTINC } & 227 . & 14.98 \\ \text { CLOTHES LEYER } & 10 . & .67\end{array}$

\section{MISCELLAiJEOUS APPLIANCES}

SaUiva

HET TUE / POOL HEATEN

KIL V

SHAEE HEATEF

$\begin{array}{ll}0 . & 0.00 \\ 0 . & 0.00 \\ 0 . & 0.00 \\ 0 . & 0.00\end{array}$




\begin{tabular}{|c|c|c|c|c|c|c|c|c|}
\hline $\begin{array}{l}\text { SUAMEN PILOT LIGAT } \\
\text { SPACE HEETIISG } \\
\text { SFACE COULINS }\end{array}$ & USE & & & & $\begin{array}{r}1.57 \\
82.78 \\
0.00\end{array}$ & & & \\
\hline UTAL CCF . & & & & & 100.00 & & & \\
\hline RECAP FOR: & - & & & & & & & \\
\hline GUEGISTEL MEASURES & 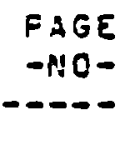 & $\begin{array}{l}\text { ANPIUAL } \\
\text { SAVINGS } \\
\text { ! }\end{array}$ & $\begin{array}{l}\text { HOMEC } \\
\text { LOW } \\
\text { S }\end{array}$ & $\begin{array}{c}\text { WNER C } \\
\text { HIGH } \\
S\end{array}$ & $\begin{array}{l}\text { OOSTS } \\
\text { PAYBACK } \\
\text { YEARS }\end{array}$ & $\begin{array}{l}\text { CONTF } \\
\text { LOJ } \\
\text { S }\end{array}$ & $\begin{array}{l}\text { CTOK } \\
\text { HIGH } \\
S\end{array}$ & $\begin{array}{l}\text { COSTS } \\
\text { PAYELCK } \\
\text { YEARS }\end{array}$ \\
\hline 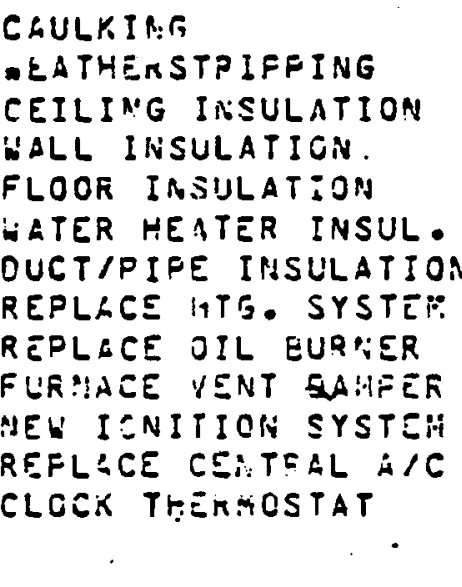 & $\begin{array}{l}=5- \\
=5- \\
=6- \\
=6- \\
=6- \\
=5- \\
=7- \\
=7- \\
=7- \\
=7- \\
=7- \\
=7- \\
=7-\end{array}$ & $\begin{array}{r}0 \\
0 \\
0 \\
158 \\
0 \\
10 \\
0 \\
0 \\
0 \\
0 \\
17 \\
0 \\
35\end{array}$ & $\begin{array}{l}0 \\
0 \\
0 \\
0 \\
0 \\
5 \\
0 \\
0 \\
0 \\
0 \\
0 \\
0 \\
35\end{array}$ & $\begin{array}{r}0 \\
0 \\
0 \\
0 \\
0 \\
35 \\
0 \\
0 \\
0 \\
0 \\
0 \\
0 \\
120\end{array}$ & $\begin{array}{l}0 \\
0 \\
0 \\
0 \\
0 \\
2 \\
0 \\
0 \\
0 \\
0 \\
0 \\
0 \\
2\end{array}$ & $\begin{array}{r}0 \\
0 \\
0 \\
1051 \\
0 \\
10 \\
0 \\
0 \\
0 \\
0 \\
1=0 \\
0 \\
50\end{array}$ & $\begin{array}{r}0 \\
0 \\
0 \\
2102 \\
0 \\
50 \\
0 \\
0 \\
0 \\
0 \\
400 \\
0 \\
150 \\
\end{array}$ & $\begin{array}{l}0 \\
0 \\
0 \\
7 \\
0 \\
3 \\
0 \\
0 \\
0 \\
0 \\
9 \\
0 \\
3\end{array}$ \\
\hline SUSGESTED MEASURES & $\begin{array}{l}P A G E \\
-N: 0- \\
---O-\end{array}$ & $\begin{array}{l}\text { ANNUAL } \\
\text { SAVINGS } \\
I\end{array}$ & $\begin{array}{l}\text { HOHEC } \\
\text { LOS } \\
\text { S }\end{array}$ & $\begin{array}{l}- \text { PIER C } \\
\text { HIGH } \\
\text { S }\end{array}$ & $\begin{array}{l}\text { OOSTS } \\
\text { EIYZACK } \\
\text { YESAS }\end{array}$ & $\begin{array}{l}\text { CCNit } \\
\text { LOW } \\
\text { g }\end{array}$ & $\begin{array}{l}\text { ACTOR } \\
\text { MIGH } \\
\text { S }\end{array}$ & $\begin{array}{l}\text { COSTS } \\
\text { FEYUAC: } \\
\text { YELFS }\end{array}$ \\
\hline 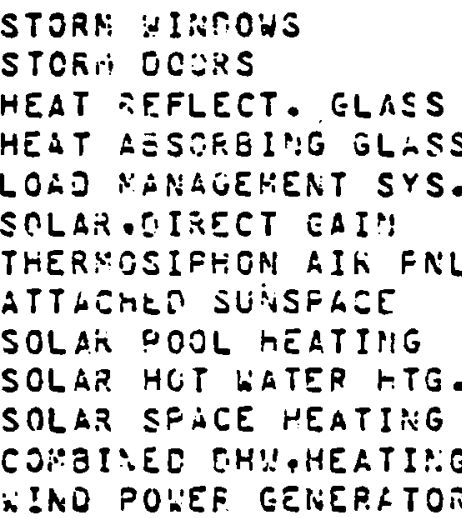 & $\begin{array}{l}-8- \\
-8- \\
-10- \\
S-10- \\
-11- \\
-13- \\
-14- \\
-15- \\
-16- \\
-16- \\
-17- \\
0-17- \\
-16-16-\end{array}$ & $\begin{array}{l}0 \\
0 \\
70 \\
70 \\
0 \\
0 \\
0 \\
0 \\
0 \\
0 \\
0 \\
0 \\
0\end{array}$ & $\begin{array}{r}0 \\
0 \\
311 \\
584 \\
0 \\
0 \\
0 \\
0 \\
0 \\
0 \\
0 \\
0 \\
0 \\
0\end{array}$ & $\begin{array}{r}0 \\
0 \\
1247 \\
1169 \\
0 \\
0 \\
0 \\
0 \\
0 \\
0 \\
0 \\
0 \\
0 \\
0\end{array}$ & $\begin{array}{l}0 . \\
0 \\
8 \\
9 \\
0 \\
0 \\
0 \\
0 \\
0 \\
0 \\
0 \\
0 \\
0\end{array}$ & $\begin{array}{r}0 \\
0 \\
389 \\
974 \\
0 \\
0 \\
0 \\
0 \\
0 \\
0 \\
0 \\
0 \\
0\end{array}$ & $\begin{array}{r}0 \\
0 \\
1481 \\
1945 \\
0 \\
0 \\
0 \\
0 \\
0 \\
0 \\
0 \\
0 \\
0\end{array}$ & $\begin{array}{r}0 \\
0 \\
5 \\
12 \\
0 \\
0 \\
0 \\
0 \\
0 \\
0 \\
0 \\
0 \\
0\end{array}$ \\
\hline
\end{tabular}

FEOJECT 1.UMEER $=$ AEZ2224.

THIS IS AUUIT NULEEF 1

CONAECT TIB̈E = 20.7 HISUTES 


\section{DISTRIBUTION}

No. of

Copies

\section{OFFSITE}

27 DOE Technical Information Center

5 Wayne Hoffman National Institute for

Social \& Economic Research Boulder, CO 80302

1 JN Franke Bonneville Power Administration Portland, OR 97208

1 Peter Back Department of Energy Washington, DC 20585

\section{ONSITE}

DOE Richland Operations Office

H. E. Ransom

65 Pacific Northwest Laboratory

WB Ashton (1)

Economics Library (2)

AL Nieves (54)

RG Rivera (1)

Publishing Coordination (2)

Technical Information (5) 